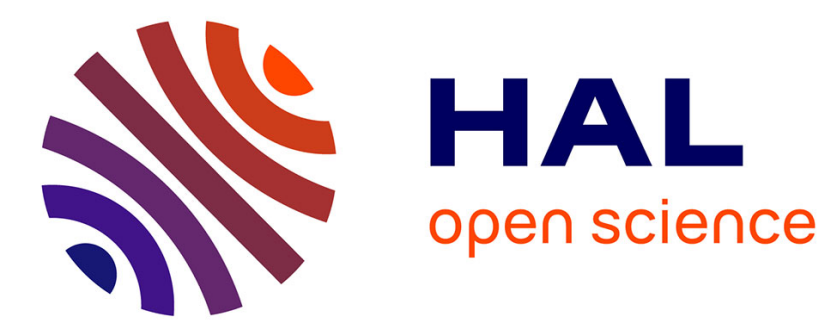

\title{
Annual cycle of humic substances in a temperate estuarine system affected by agricultural practices
}

Matthieu Waeles, Ricardo D. Riso, Benoit Pernet-Coudrier, Francois Quentel, Gaël Durrieu, Cyril Tissot

\section{- To cite this version:}

Matthieu Waeles, Ricardo D. Riso, Benoit Pernet-Coudrier, Francois Quentel, Gaël Durrieu, et al.. Annual cycle of humic substances in a temperate estuarine system affected by agricultural practices. Geochimica et Cosmochimica Acta, 2013, 106, pp.231-246. 10.1016/j.gca.2012.12.040 hal-00816961

\section{HAL Id: hal-00816961 \\ https://hal.univ-brest.fr/hal-00816961}

Submitted on 23 Apr 2013

HAL is a multi-disciplinary open access archive for the deposit and dissemination of scientific research documents, whether they are published or not. The documents may come from teaching and research institutions in France or abroad, or from public or private research centers.
L'archive ouverte pluridisciplinaire HAL, est destinée au dépôt et à la diffusion de documents scientifiques de niveau recherche, publiés ou non, émanant des établissements d'enseignement et de recherche français ou étrangers, des laboratoires publics ou privés. 


\title{
Annual cycle of humic substances in a temperate estuarine system affected by agricultural practices
}

\author{
Matthieu Waeles $^{\text {a,b,* }}$, Ricardo Riso ${ }^{\text {a,b }}$, Benoît Pernet-Coudrier ${ }^{\text {a,b }}$, \\ François Quentel $^{\mathrm{a}, \mathrm{c}}$, Gaël Durrieu ${ }^{\mathrm{d}}$, Cyril Tissot ${ }^{\mathrm{a}, \mathrm{e}}$ \\ ${ }^{\text {a } U n i v e r s i t e ́ ~ E u r o p e ́ e n n e ~ d e ~ B r e t a g n e, ~ B r e s t, ~ F r a n c e ~}$ \\ ${ }^{\mathrm{b}}$ Université de Bretagne Occidentale, IUEM, LEMAR, UMR-CNRS 6539, Equipe Chimie Marine, Place N. Copernic, 29280 Plouzané, France \\ ${ }^{\mathrm{c}}$ Université de Bretagne Occidentale, UMR-CNRS 6521, 6 Avenue V. Le Gorgeu, CS 93837, 29238 Brest Cedex 3, France \\ ${ }^{\mathrm{d}}$ Laboratoire PROTEE, Université du Sud Toulon-Var, BP 132, 83957 La Garde, France \\ ${ }^{\mathrm{e}}$ Laboratoire GEOMER, UMR LETG 6554 CNRS, FR 2195, IUEM-UBO, Place N. Copernic, 29280 Plouzané, France
}

Received 6 March 2012; accepted in revised form 28 December 2012; available online 8 January 2013

\begin{abstract}
Although widely studied for their chemical structures and properties (e.g., metal complexation, growth stimulation of planktonic species), humic substances (HS) have been very poorly quantified in fluvial and estuarine waters. In this monthly basis study, we determined HS concentrations (by Adsorptive Square Wave Cathodic Stripping Voltammetry) along the entire river-seawater gradient of the Penzé estuary (NW France), with the aim to characterize the export of these compounds. In this watershed where agricultural activities are predominant, manuring activities were identified as being the main source of dissolved organic carbon (DOC) and HS. HS concentrations varied usually within a narrow range in fluvial waters, i.e., $1.8 \pm 0.4 \mathrm{mgC} \mathrm{L}^{-1}(150 \pm 40 \mu \mathrm{M})$, but increased significantly as the first flood of autumn occurred $\left(>4 \mathrm{mgC} \mathrm{L}^{-1}\right.$ in river and upper estuary). At this time, HS accounted for a very high proportion of DOC $(>80 \%)$. As evidenced by the increasing contribution of HS to DOC, and by the increasing contribution of small colloidal HS species; this autumnal flood increase should be attributed to a greater retention and transformation of organic matter on soils over the hotter, drier, and lighter period preceding the first autumnal flood. In the mixing zone, HS displayed mostly conservative behaviour, although some removals were occasionally observed. Overall, our study suggests that preservation of HS could be relatively important during their transfer across macrotidal temperate estuaries, at least in systems affected by agricultural practices.
\end{abstract}

(c) 2013 Elsevier Ltd. All rights reserved.

\section{INTRODUCTION}

Dissolved organic matter (DOM) plays major roles in oceanic and global biogeochemical processes. Although small compared to terrestrial crust, this reservoir $(\sim 700 \mathrm{Gt} C)$ is approximately equal to atmospheric $\mathrm{CO}_{2}$ and accounts for $>90 \%$ of the organic carbon in the oceans, making it one of the Earth's largest active carbon pools (Siegenthaler and Sarmiento, 1993; Bianchi, 2011). Among

\footnotetext{
* Corresponding author at: Université de Bretagne Occidentale, IUEM, LEMAR, UMR-CNRS 6539, Equipe Chimie Marine, Place N. Copernic, 29280 Plouzané, France.

E-mail address: waeles@univ-brest.fr (M. Waeles).
}

the various sources, rivers are now recognized as a significant supplier of dissolved organic carbon (DOC) to oceans (Raymond and Bauer, 2001; Seitzinger et al., 2005). Massbalance calculations suggest an approximate flux of 0.2 0.4 Gt C per year (Hedges et al., 1997; Cai, 2011). Indeed, the entire oceanic DOM pool would be replaced by terrestrial DOM in less than 3000 years (Köhler et al., 2003). Riverine DOM is considered to be degraded by microorganisms in the coastal ocean (Chin-Leo and Benner, 1992; Lohrenz et al., 2010). It is also removed from seawater by photochemical processes (Kieber et al., 1990; Miller and Moran, 1997; Spencer et al., 2009). Despite its importance, the composition and fate of riverine DOM has been poorly determined and remains one of the major 
concerns in contemporary biogeochemistry (Hedges et al., 1997; Opsahl and Benner, 1997; Hernes and Benner, 2003; Bianchi, 2011).

Refractory organic matter (ROM), also known and henceforth referred to as humic substances (HS), is known to be a major component of DOM in river and coastal waters $(15-100 \%$ in freshwaters; $10-50 \%$ in estuaries and coastal waters; Obernosterer and Herndl, 2000; Chanudet et al., 2006). Terrestrial humic material, deriving mainly from decay of lignin-containing plants, is thought to account for most of the humic substances present in these systems (Ehrhardt, 1984; Tremblay and Gagné, 2009). Among various important characteristics, HS have been shown to enhance solubility of organic pollutants and pesticides (Chiou et al., 1986; Tanaka et al., 1997; Blasioli et al., 2008); stimulate growth rate and biomass production of dinoflagellates (Doblin et al., 1999; Gagnon et al., 2005); and provide an energy source for a variety of estuarine sedimentary microorganisms under both aerobic and anaerobic conditions (Alberts and Filip, 1994; Rocker et al., 2012). Similar to DOM, the behaviour of HS during transport to the marine environment is still very unclear (Dittmar and Kattner, 2003). Indeed, the study of HS in estuarine salinity gradients, although of vital importance for resolving this question, has been very poorly undertaken mainly because of the difficulties inherent to their determination. Currently, most studies on the subject have been devoted to humic acids (HA). These studies have shown unambiguously that humic acids flocculate during estuarine mixing (Sholkovitz et al., 1978; Fox, 1983; Ertel et al., 1986). HA, however, represent only a fraction of HS. By contrast, fulvic acids (FA), a predominant fraction of HS in freshwater compared to HA (Tipping et al., 1988; Cory et al., 2010), appear to not be removed (Ertel et al., 1986; Otero et al., 2003; Tremblay and Gagné, 2009) which suggests a possible global preservation of HS during transfer to coastal waters.

In this study, we investigated the behaviour of HS in the salinity gradient of the Penzé estuary (NW France). Despite its low discharge regime, this estuary can be regarded as a typical temperate system affected by agricultural practices. The whole salinity gradient has been considered (12 stations) and the study was conducted on an annual basis (12 sampling campaigns in 2008 and three sampling campaigns in 2009) in order to take into account the seasonal changes of the terrestrial environment. To our knowledge, such an approach has never been undertaken before. Our objectives were (1) to determine the dynamic of HS in this kind of riverine-estuarine system impacted by agricultural activities, (2) to examine its behaviour across the salinity gradient and (3) to assess the importance of HS in the export of DOC to the coastal area.

\section{MATERIAL AND METHODS}

\subsection{Study area}

The Penzé River (North Brittany, France) is $28 \mathrm{~km}$ long and has a drainage area of $141 \mathrm{~km}^{2}$. This system collects the waters from a very poorly industrialized catchment but where extensive agricultural activities have been developed for decades. Soil occupancy is mainly agricultural with arable and permanently cultivated areas representing $\sim 36 \%$ and heterogeneous agricultural areas accounting for $\sim 33 \%$. Meadows (7\%), moor and peat bogs $(3 \%)$ and forests $(0.7 \%)$ are the remaining non-urbanized areas. Agricultural activities mainly consist of farming and vegetable cultivation. The watershed area contains about 102,000 pigs, 1,600,000 poultry and 17,500 cattle.

The water discharge at the village of Penzé usually fluctuates in the range $0.5-15 \mathrm{~m}^{3} \mathrm{~s}^{-1}$ (average $2.83 \mathrm{~m}^{3} \mathrm{~s}^{-1}$ over the 1967-2009 period) and the specific discharge of the river is about $20 \mathrm{~L} \mathrm{~s}^{-1} \mathrm{~km}^{-2}$. Evolution of the water discharge in this system is constrained by a temperate oceanic climate. Rain falls the year round (annual rainfall usually around $1000 \mathrm{~mm}$ ), with a distinct maximum during winter, mainly from the regular procession of weather fronts that move east across the Atlantic. As a result, $\sim 60 \%$ of the annual flow generally occurs in the December-March period.

The estuary is situated between the village of Penzé and the Morlaix Bay, covering a distance of ca. $10 \mathrm{~km}$ (Fig. 1). It is subjected to a macrotidal regime as the tidal range fluctuates between 1.8 and $9.2 \mathrm{~m}$. The residence time of water within the estuary, which is highly dependent on the tide and the river flow, varies between 2 days at spring tide and 15 days at neap tide and low discharge.

\subsection{Sampling}

Twelve cruises were conducted on a monthly basis over the year 2008. Additional sampling was also carried out at key periods in 2009 (May, July and November). Waters were collected along the whole salinity gradient, at 12 field stations (six field stations for 2009 sampling) between the village of Penzé and the Morlaix Bay (Fig. 1). The stations were selected with the aim of covering the whole freshwater-seawater mixing zone. Approximate salinity at station $\mathrm{S}_{i}$ was $i$, where $i=0,1,2,3,5,8,11,14,17,22,27,34$. $\mathrm{S}_{0}$ was always situated at the Penzé village in order to have fluvial reference, out from the turbid area, whereas the 11 remaining locations (i.e., $\mathrm{S}_{1}-\mathrm{S}_{34}$ ) were situated between the haline front (around $48^{\circ} 37^{\prime} \mathrm{N}$ ) and the marine waters (above $48^{\circ} 41^{\prime} \mathrm{N}$ ). The sampling was realized at neap tide ( $\sim 7-10$ days following a spring tide peak), between the stand of tide and the first flood. It was performed from a Zodiac inflatable boat with 500-mL and 1-L-HDPE-Nalgene ${ }^{\circledR}$ bottles. Water was sampled by hand at ca. $0.5 \mathrm{~m}$ below the surface with the arm fully covered with a plastic glove $\left(92 \mathrm{~cm}\right.$, Polysem $\left.{ }^{\circledR}\right)$. Table 1 summarizes the various conditions encountered during this study.

\subsection{Filtration and ultrafiltration}

All water samples were filtered in the laboratory within $2 \mathrm{~h}$ of collection. To separate HS from the suspended particulate matter (SPM), samples were filtered through 0.45 $\mu \mathrm{m}$ Millipore ${ }^{\circledR}$ HA filters. The filtrate was then acidified to $\mathrm{pH} 2\left(\mathrm{HCl}\right.$, suprapur ${ }^{\circledR}$, Merck), and stored at $4{ }^{\circ} \mathrm{C}$ until further analysis. Particulate organic carbon (POC), Chlorophyll- $a(\operatorname{chl} a)$ and phaeopigments (phaeo) were collected on 


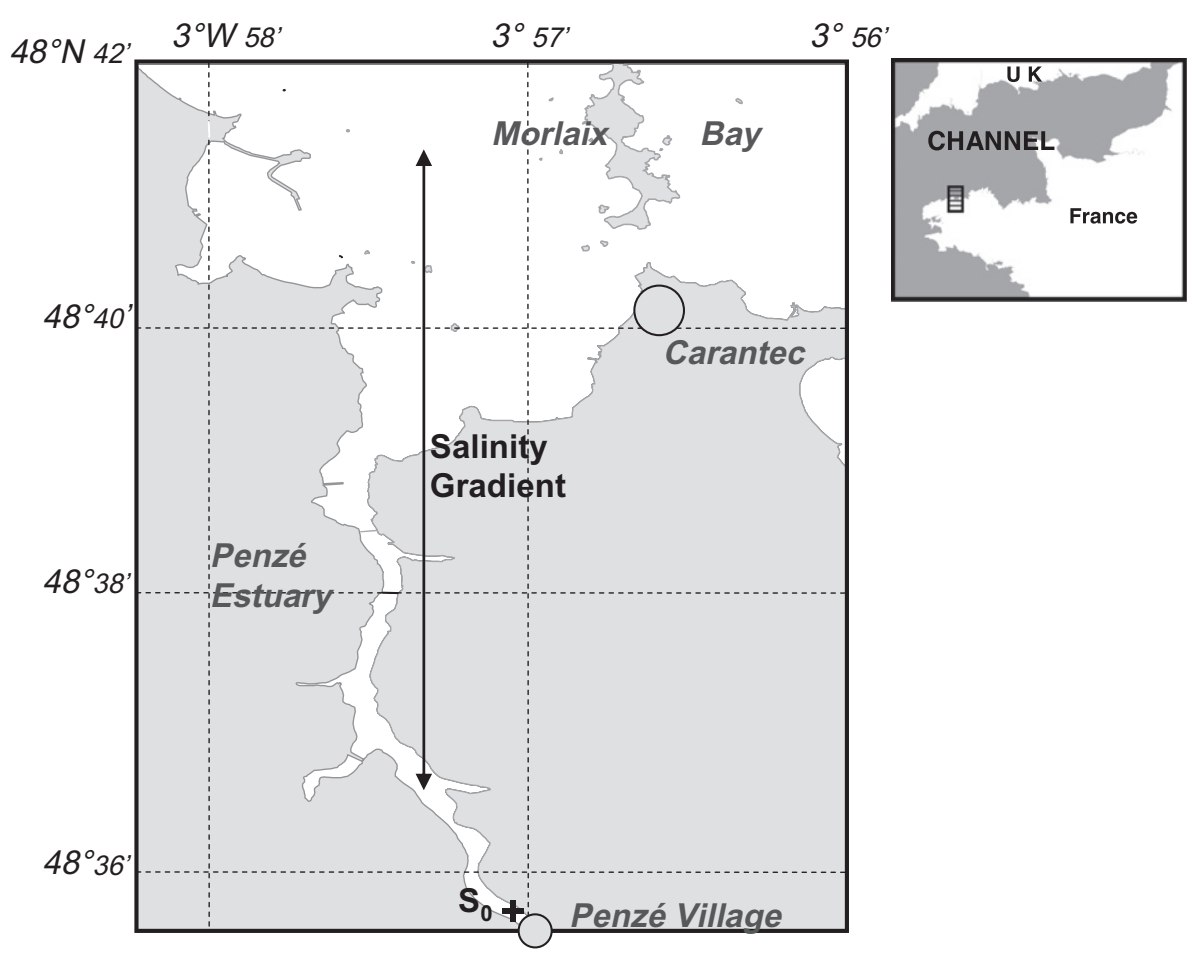

Fig. 1. Study area and approximate position of the salinity gradient during sampling conditions (neap tide, low tide).

Table 1

Sampling dates and conditions; number in parentheses for water discharge indicates the variation of this parameter during the 3 days before sampling. Important discharge variations are in bold.

\begin{tabular}{lll}
\hline Sampling date & Water discharge $\left(\mathrm{m}^{3} \mathrm{~s}^{-1}\right)$ & Tidal range $(\mathrm{m})$ \\
\hline 7 January 2008 & $3.17(\mathbf{+ 7 3} \%)$ & 5.1 \\
4 February 2008 & $5.52(-17 \%)$ & 4.0 \\
3 March 2008 & $2.72(+2 \%)$ & 2.3 \\
1 April 2008 & $4.38(+15 \%)$ & 2.3 \\
14 May 2008 & $2.96(+\mathbf{+ 7 0} \%)$ & 4.1 \\
13 June 2008 & $2.25(-8 \%)$ & 4.0 \\
15 July 2008 & $1.26(-25 \%)$ & 4.0 \\
27 August 2008 & $0.94(-1 \%)$ & 4.0 \\
25 September 2008 & $1.57(+4 \%)$ & 4.1 \\
23 October 2008 & $1.39(+3 \%)$ & 4.0 \\
25 November 2008 & $4.86(+\mathbf{5 5} \%)$ & 5.6 \\
10 December 2008 & $7.92(-9 \%)$ & 5.6 \\
4 May 2009 & $1.97(-15 \%)$ & 4.7 \\
17 July 2009 & $0.69(+6 \%)$ & 3.8 \\
13 November 2009 & $6.36(+\mathbf{2 6 0} \%)$ & 5.5 \\
\hline
\end{tabular}

0.7- $\mu \mathrm{m} \mathrm{GF} / \mathrm{F}$ Whatman filters. For DOC, water samples were also passed through $\mathrm{GF} / \mathrm{F}$ membranes and were stored at $-20{ }^{\circ} \mathrm{C}$ in glass containers. Membranes and glass containers were precombusted at $450{ }^{\circ} \mathrm{C}$ for $4 \mathrm{~h}$ before use. The filters used for POC were decarbonated by $\mathrm{HCl}$ fumes.

Separation of colloidal HS was conducted on samples collected at key periods in 2009 (May, July and November). For this purpose, a sequential ultrafiltration procedure (frontal mode) was carried out after passing the samples through a $0.22-\mu \mathrm{m}$ filter (HATF, Millipore). This procedure, which allows isolation of six fractions, was described in Waeles et al. (2008). Briefly, the ultrafiltration is conducted with a 8200 -Amicon ${ }^{\circledR}$-stirred cell and with five types of membranes. Nominal sizes of the membranes were 300 , 50, 30, 10 (polyether sulfone, Biomax PB, Millipore) and $5 \mathrm{kDa}$ (regenerated cellulose, Ultracel PL, Millipore). Using a concentration mode (Wen et al., 1996), a pressure was applied to push the sample through the membrane. In order to minimize artefacts caused by coagulation of colloids at the membrane surface, small flow rates $\left(1.5-4.5 \mathrm{~mL} \mathrm{~min}^{-1}\right)$ and small concentrations factors (3-13) were used. It should be noted that concentration factors were kept as constant as possible for each nominal cut-off. In addition, a stirring over the membrane was also applied to minimize concentration polarization effect due to the densification of macromolecules at the membrane surface (Burba et al., 1998). HS were then analyzed from each permeate acidified to $\mathrm{pH} 2$ with $\mathrm{HCl}$. Prior to use, all the items employed for sampling, filtration and sample storage were washed with diluted hydrochloric acid (pH 2, $\mathrm{HCl}$ suprapur $^{\circledR}$, Merck), then rinsed with Milli-Q Element ${ }^{\circledR}$ water.

\subsection{Analyses}

HS were analyzed by Adsorptive Square-Wave Cathodic Stripping Voltammetry at a static mercury drop electrode using the method developed by Quentel et al. (1986). This simple and rapid method, based on adsorption of the complex formed by HS with molybdenum and originally developed for marine waters, has also proved its usefulness in freshwaters (Chanudet et al., 2006). The voltammetric measurements were performed with a potentiostat/galvanostat $\mu$-AutolabIII unit controlled by GPES 4.9 software and operating on a three electrode basis. The working electrode 
was a static mercury drop electrode (SMDE), Metrohm model $663 \mathrm{VA}$, with a mercury drop size of $0.52 \mathrm{~mm}^{2}$. An $\mathrm{Ag} / \mathrm{AgCl}\left(3 \mathrm{~mol} \mathrm{~L}^{-1} \mathrm{KCl}\right.$, Suprapur) electrode and a carbon electrode were used as the reference and the auxiliary electrodes, respectively. A small amount of $\mathrm{Mo}(\mathrm{VI})$ $\left(0.105 \mu \mathrm{mol} \mathrm{L}{ }^{-1}\right)$ was added to the acidified $\left(0.01 \mathrm{~mol} \mathrm{~L}^{-1}\right.$ $\mathrm{HCl}$ ) sample. As shown in (Quentel et al., 1987), this allows the formation of the Mo-HS complex at the working electrode with an adequate sensitivity. The sample was then deaerated with nitrogen for $10 \mathrm{~min}$ and the deposition at $-300 \mathrm{mV}$ (vs $\mathrm{Ag} / \mathrm{AgCl}, 3 \mathrm{~mol} \mathrm{~L}^{-1} \mathrm{KCl}$ ) was performed with stirring. Under this potential, the Mo(VI)-HS complex is formed and reduced to $\mathrm{Mo}(\mathrm{V})-\mathrm{HS}$ following its adsorption at the mercury drop. After the deposition time (100$240 \mathrm{~s}$ ), the stirring was stopped and, following a 20 -s rest period, the scan was initiated to the negative direction using the square wave mode. Under this cathodic scan, the $\mathrm{Mo}(\mathrm{V})-\mathrm{HS}$ complex is stripped and reduced to $\mathrm{Mo}(\mathrm{IV})$, giving a signal at approximately $-525 \pm 25 \mathrm{mV}$ (Quentel and Elleouet, 2001). The operational parameter values used were the same as described in Quentel and Filella (2008): i.e., $50-\mathrm{Hz}$ frequency, $1-\mathrm{mV}$ step potential and $50-\mathrm{mV}$ pulse amplitude. Because this technique is standard-dependent due to adsorption properties of HS, we followed the recommendations of Quentel and Filella (2008) to use standard additions of the same substances, i.e., Suwannee River fulvic acid (IHSS, R 1S101F). For a 3 min deposition time, the detection limit of the method is $2.4 \mu \mathrm{gC} \mathrm{L}^{-1}(0.2 \mu \mathrm{M})$ and the precision is lower than $5 \%$. In order to stay within the linear range of the method (i.e., $<100 \mathrm{nA}$ using the above electrochemical conditions), a dilution of the sample is required for concentrations over $0.2 \mathrm{mgC} \mathrm{L}^{-1}$ (Quentel et al., 1987). All solutions were prepared with ultrapure water $(>18 \mathrm{M} \Omega$ ) from a Milli-Q Element system (Millipore, Billerica, MA, USA) and the $\mathrm{HCl}$ stock solution used was $30 \%$ Suprapur from Merck. The Mo(VI) stock solution (40 ppm) was prepared in $10^{-2} \mathrm{~mol} \mathrm{~L}^{-1} \mathrm{HCl}$ by dissolving a 1000 ppm standard solution (Fluka). Fulvic acid standard solutions were also prepared in $10^{-2} \mathrm{~mol} \mathrm{~L}^{-1} \mathrm{NaOH}$ by weighing the appropriate mass of the R 1S101F-IHSS standard powder (carbon content: $55.44 \mathrm{wt} . \%$ ).

Salinity $(S)$ and temperature $(T)$ were measured in situ with a WTW ProfiLine LF 197 probe $\left( \pm 0.1\right.$ and $0.1{ }^{\circ} \mathrm{C}$ precision, respectively). Suspended particulate matter (SPM) concentrations were determined by gravimetry with an uncertainty lower than 5\%. POC was assessed using a ThermoQuest - FlashEA CHN analyser. Precision on POC quantification was about $5 \%$. Chla and phaeo were extracted and measured by Lorenzen's method (Lorenzen, 1967 ) with an $8 \%$ precision. DOC measurements were performed using a TOC-V analyser (Shimadzu), calibrated using sodium hydrogen phtalate standard solutions, with an accuracy of $10 \mu \mathrm{gC} \mathrm{L} \mathrm{L}^{-1}(0.8 \mu \mathrm{M})$.

\subsection{Interpretation of mixing diagram and fluxes calculation}

After plotting HS concentrations as a function of salinity, non-conservative mixing was tested by fitting a second-order polynomial model ( $\mathrm{HS}=a+b \mathrm{~S}+c \mathrm{~S}^{2}$ ) to each set of data (Rochelle-Newall and Fisher, 2002). In order to determine whether this $\mathrm{m}$ model gives a significantly better fit to the data than the linear model ( $\mathrm{HS}=a+b \mathrm{~S}$ ), corresponding to a conservative mixing, an $F$-test was then conducted. $F_{\exp }$ was given by:

$F_{\exp }=\frac{(S S 1-S S 2) \times(n-3)}{S S 2}$

where $S S 2$ and $S S 1$ are the residual sum of squares of second-order model (three parameters) and linear model (two parameters), respectively; $n$ is the number of data points $(n=12)$. The null hypothesis, i.e., second-order model not providing a better fit than linear model, is rejected if $F_{\exp }$ is greater than the critical value of the $F$ distribution for a 0.05 false-rejection probability. Under this null hypothesis, the mixing was considered as being not significantly nonconservative (i.e., conservative).

Annual flux of HS being exported from the Penzé catchment was obtained from the theoritical river end-member concentrations (i.e., the mixing model intercept $a_{i}$ where $i$ is the sampling campaign) as determined by the appropriate non-conservative (second-order) or conservative (linear) mixing model. Because each sampling campaign covers the whole salinity gradient, each $a_{i}$ could be considered as integrating HS variations of the river over a certain time. Considering the variation of the residence time before each sampling campaign, this time is on the order of a week. Then, the annual flux of HS $(F)$ was assessed using the annual discharge-weighted mean concentration (DWM) drawing from Filoso et al. (2003):

$\mathrm{DWM}=\frac{\sum_{i=1}^{12} a_{i} \times Q_{7, i}}{\sum_{i=1}^{12} Q_{7, i}} ; F=\mathrm{DWM} \times Q_{y}$

where $Q_{7, i}$ is the mean discharge for the week preceding each sampling campaign $i$ and $Q_{y}$ is the mean annual discharge. The approach used here for flux quantification would have probably benefited from a higher sampling frequency but was done to include the wider possible range of hydrological conditions over the year. This care is illustrated by the closed values between water discharge conditions during sampling (mean of $Q_{7, i}$ values: $\left.3.1 \pm 2.2 \mathrm{~m}^{3} \mathrm{~s}^{-1}, n=12\right)$ and water discharge conditions over the year $2008\left(3.3 \pm 2.2 \mathrm{~m}^{3} \mathrm{~s}^{-1}, n=365\right)$. It is worth noting however that the lack of sampling frequency is counterbalanced by the 12 estuarine profiles obtained in 1 year; each profile integrating variations of HS concentration in the river end-member over a certain time $(\sim 1$ week $)$.

\section{RESULTS}

\subsection{Seasonal variations of the hydrological and biogeochemical characteristics}

Daily water discharge of the Penzé River over 2008 and 2009 fluctuated between $0.25 \mathrm{~m}^{3} \mathrm{~s}^{-1}$ and $16.6 \mathrm{~m}^{3} \mathrm{~s}^{-1}$ (Fig. 2a). During the seasonal cycle, two distinct periods can be identified: the November-March period which is characterized by relatively high discharges and the AprilOctober period which is drier. Although this distinction was more pronounced for 2009, such a pattern of evolution is in accordance with the usual observations in Brittany 

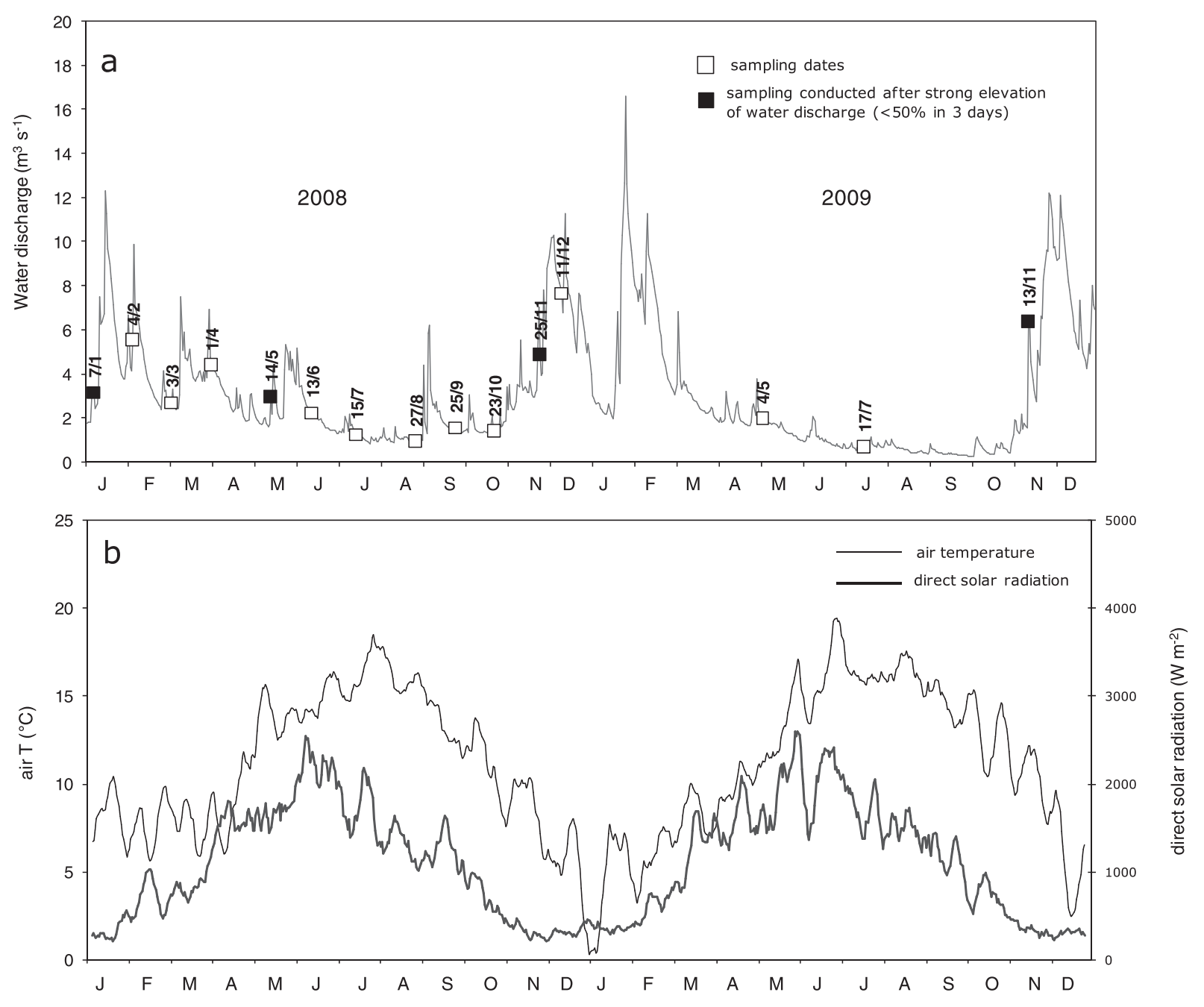

C
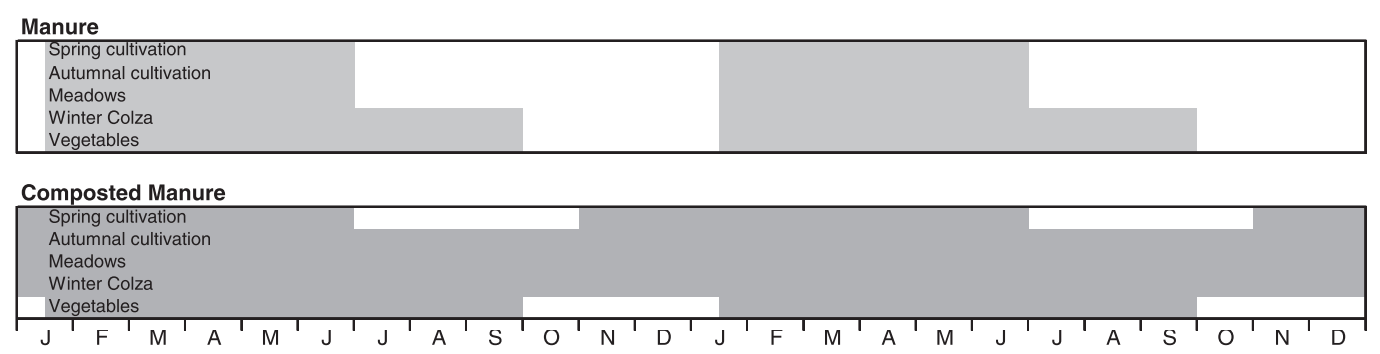

Fig. 2. (a) Seasonal water discharge (Penhoat field station, Agence de l'eau Loire-Bretagne) and dates of sampling (see also Table 1); (b) air temperature at Pleyber-Christ (Météo France) and direct solar radiation at Guipavas (Météo France). Air temperature and direct solar radiation curves were smoothed with a simple moving average of 9 days; (c) Allowed periods for application of fresh manure and composted manure according to land use.

Rivers. On few occasions, sampling was conducted under strong elevation of the discharge (January-08, May-08, November-08 and November-09; see also Table 1). Of particular importance were precipitations during the 2 days preceding our sampling of November-08 and November09 (19.4 and $28.8 \mathrm{~mm}$, respectively). Air temperature and direct solar radiation over the studied period ranged within $3-19^{\circ} \mathrm{C}$ and $200-2500 \mathrm{~W} \mathrm{~m}^{-2}$, respectively, with the lowest values encountered in winter (Fig. 2b). Direct solar radia- tion maxima occurred around June whereas high temperatures were found over the entire summer.

Variations of $T$, SPM, POC:SPM ratio and chla:phaeo ratio are plotted in Fig. 3. Over the seasonal survey, water temperature varied from 7.0 to $18.0^{\circ} \mathrm{C}$. The gradual increase of the temperature occurred mainly in the April-June period whereas the cooling down was principally observed from September to November. Differences between marine and fluvial waters were usually under $2{ }^{\circ} \mathrm{C}$. 

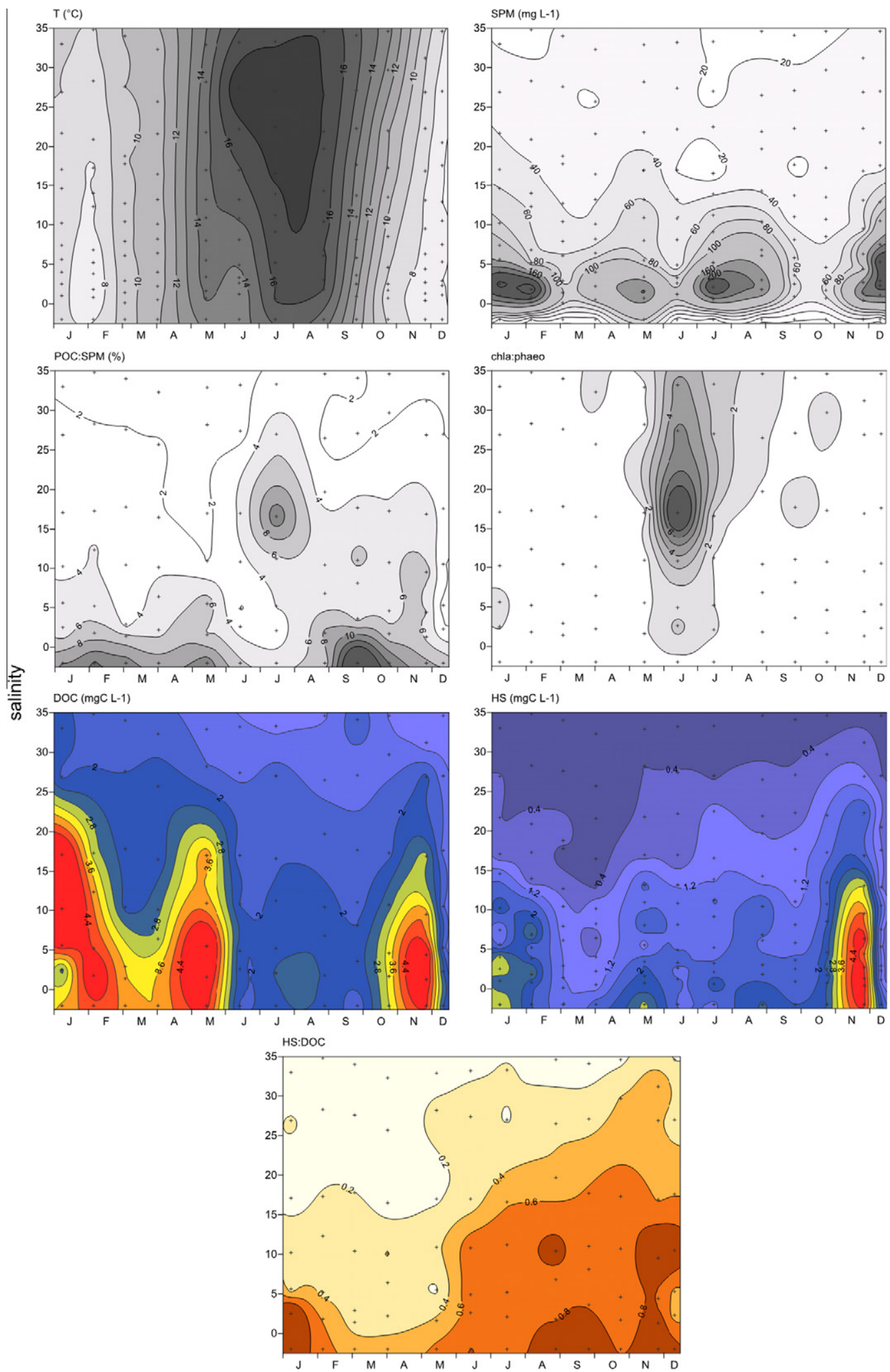

Fig. 3. Variations over 2008 of water temperature, SPM, POC:SPM ratio, chla:phaeo ratio, humic substances (HS), dissolved organic carbon (DOC) and HS-to-DOC ratio along the salinity gradient of the Penzé estuary.

SPM fluctuated between 5 and $300 \mathrm{mg} \mathrm{L}^{-1}$, with a pronounced accumulation of particles close to the haline front. Such an accumulation of particles ensues from the tidal asymmetry and is a common feature of macrotidal estuaries (Jay and Musiak, 1994; Brenon and Le Hir, 1999). According to the variations of the chla:phaeo ratio, 
phytoplanktonic species in good physiological condition were encountered in June, in the downstream section of the estuary (ratios over 4 at $S>10$ ). These species corresponded to Alexandrium minutum, which blooms almost every year at this period in the Penzé estuary (Maguer et al., 2004). POC accounted for $\sim 10 \%$ of SPM in the river. In winter, spring and autumn, the POC:SPM ratio rapidly decreased downward (to values close to $2 \%$ ) indicating that organic particles had a continental origin. In summer, the development of phytoplankton enhanced POC:SPM values at mid-estuary (POC:SPM $>4 \%$ in the salinity range 10-25).

\subsection{Seasonal variations of DOM and HS}

Seasonal variations of DOM and HS are also depicted in Fig. 3. DOC concentrations were in the range $0.9-5.8 \mathrm{mgC} \mathrm{L}^{-1}(75-480 \mu \mathrm{M})$ and strongly varied over the seasonal cycle. Relatively high concentrations were found during winter and spring 2008 (around $4 \mathrm{mgC} \mathrm{L}^{-1}$ in the upstream part), then suddenly decreased from May to June and were low (generally under $2.4 \mathrm{mgC} \mathrm{L}^{-1}$ ) during summer and early autumn. During autumn, concentrations rapidly increased and a maximum, with values close to winter values, was observed in November. Along the salinity gradient, the decrease in concentration was mainly driven by the dilution of fluvial waters with marine waters that contained lower DOC (i.e., in the range $0.9-2.0 \mathrm{mgC} \mathrm{L}^{-1}$ ). HS concentrations showed variations in the range $0.07-$ $4.8 \mathrm{mgC} \mathrm{L}^{-1}(6-400 \mu \mathrm{M})$. HS levels were relatively high during winter (January and February) with values over $2 \mathrm{mgC} \mathrm{L}^{-1}$ at low salinities, then decreased and were low throughout spring and summer. Beginning in October, a rapid increase occurred and maximum concentrations were observed in November. At this time of the year, particularly high levels were observed in the upper estuary with HS concentrations exceeding $4 \mathrm{mgC} \mathrm{L}^{-1}$.

Similar to DOC, HS concentrations decreased downstream as the result of dilution with marine waters. The contribution of HS-to-DOM in the Penzé estuary was also fairly variable. HS accounted for less than $60 \%$ of DOC over the February-May period. Then, this ratio increased substan- tially and was over $60 \%$ during summer, fall and early winter, in a large upstream part of the system $(S<15)$. It is worth noting that this increase was mainly associated to a decrease in DOC. Because HS were fairly constant over the same period, the change of the DOC composition must be attributable to a loss of the most labile species. The maximum contribution of $\mathrm{HS}$ to DOC was observed in November (HS:DOC $>80 \%$ in the salinity range $0-10$ ) and coincided with the very strong increase of HS concentrations. Along the salinity gradient, HS:DOC decreased as the result of mixing with marine waters of lower HS:DOC ratio $(<0.2)$.

\subsection{Colloidal distribution of HS}

Fig. 4 displays HS concentrations and distributions in the various fractions under $0.22 \mu \mathrm{m}$. It is worth noting that the total dissolved concentrations $(<0.22 \mu \mathrm{m})$ for the three sampling campaigns of 2009 were comparable to the amounts reported for the same periods in 2008: total dissolved HS were relatively low in May-09 and July-09 (under $2 \mathrm{mgC} \mathrm{L}^{-1}$ with HS:DOC ratio of $\sim 50 \%$ ) whereas much higher levels $\left(>4 \mathrm{mgC} \mathrm{L}^{-1}\right.$ in the upstream part with HS:DOC ratio of $\sim 80 \%$ ) were measured in November- 09 . The colloidal distribution of HS was also clearly variable. In May, high molecular weight species (over $50 \mathrm{kDa}$ ) dominated HS along the whole salinity gradient and accounted for $53 \pm 13 \%(n=6)$ of the $<0.22-\mu \mathrm{m}$ pool. By contrast, HS were observed in smaller size ranges in July and November. At these periods, HS consisted mainly of species in the range $5-50 \mathrm{kDa}$ which accounted for $57 \pm 11 \% \quad(n=6)$ and $61 \pm 15 \%(n=6)$, respectively. Truly dissolved species $(<5 \mathrm{kDa})$ represented $17 \pm 7 \%(n=18)$ for all three periods. Along the salinity gradient, the contribution of large colloids $(>50 \mathrm{kDa})$, small colloids $(5-50 \mathrm{kDa})$ or truly dissolved species $(<5 \mathrm{kDa})$ did not vary significantly suggesting no major reaction under estuarine mixing.

\subsection{Mixing behaviour and fluxes}

Fig. 5 displays the HS-salinity distributions with fitted lines by second-order model. In almost all cases (occurrence
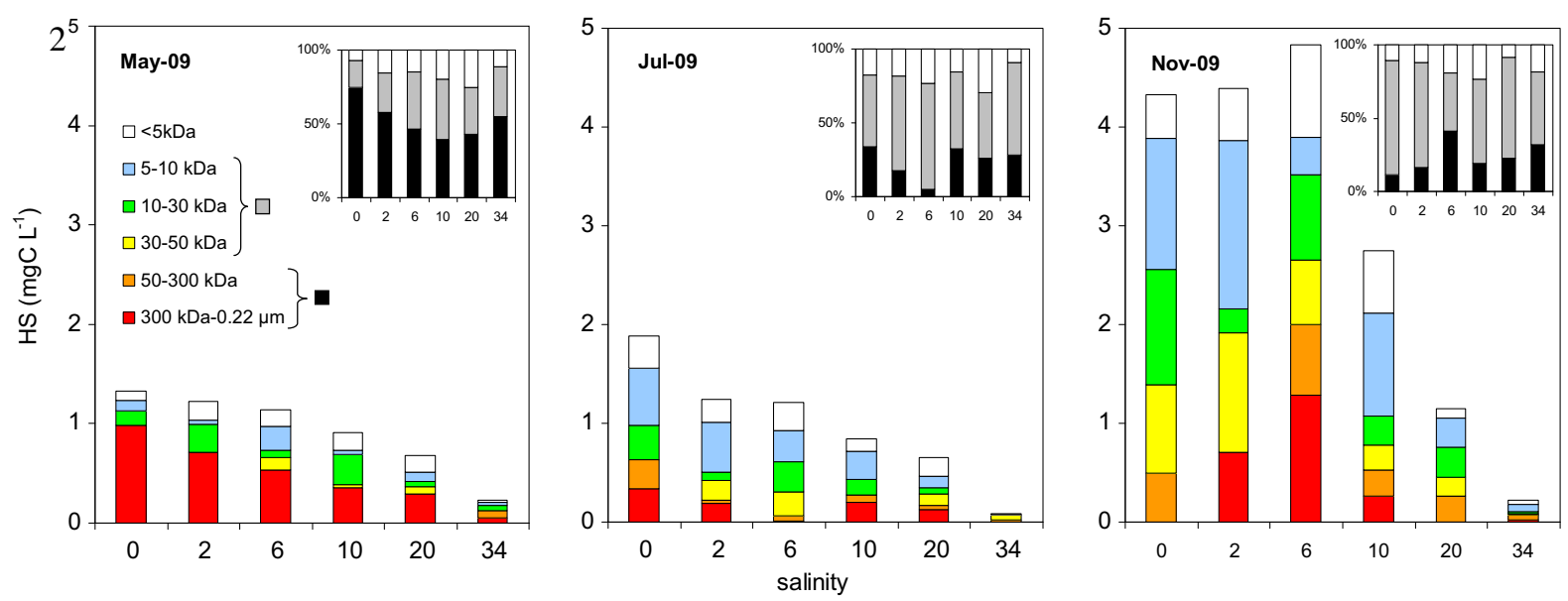

Fig. 4. Distribution of HS in the various colloidal fractions under $0.22 \mu \mathrm{m}$ along the salinity gradient of the Penzé estuary (May, July and November 2009), plotted in term of concentrations (main figures) and percent contribution (inset figures). 


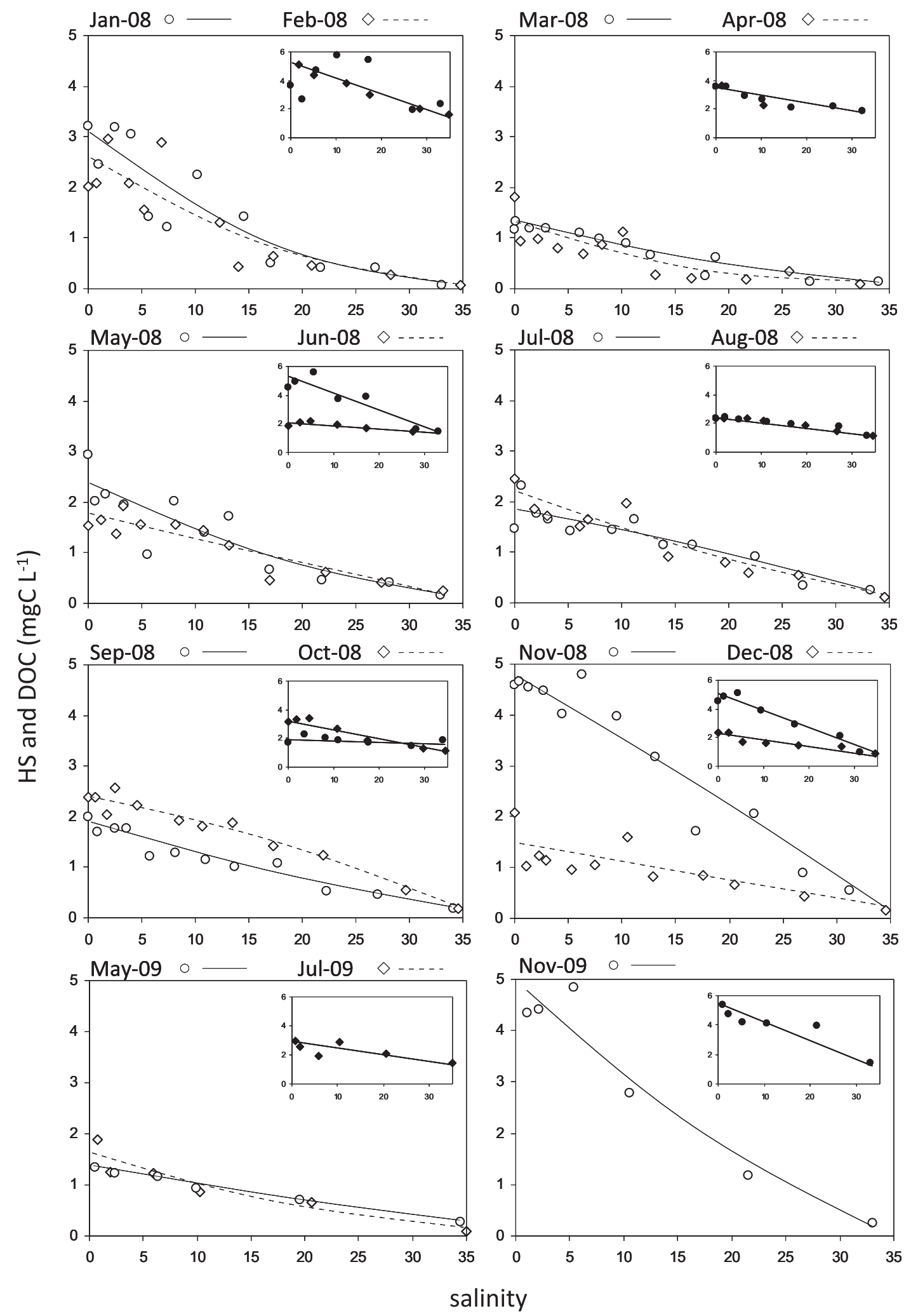

Fig. 5. HS-salinity distributions in the Penzé estuary with fitted lines by second-order model $\left(\mathrm{HS}=a+b \mathrm{~S}+c \mathrm{~S}^{2}\right)$. Insets show DOC-salinity distributions with theoretical mixing lines.

10/15), HS displayed conservative behaviour along the salinity gradient. Negative deviations indicative of removal were apparent for several data sets (in particular from
January to May-2008). Loss of HS could be perceptible at mid-estuary (January, February and April-08). In some occasions, a decrease of HS concentrations was also 
noticeable within the freshwater reaches (April, May and November-08). It is important, however, to keep in mind that HS losses, if they exist, are probably limited in the system. Indeed, $F$-tests revealed non significant deviations in every situation (Table 2). Variations of DOC along the salinity gradient are also described in Fig. 5 (insets). In absence of any obvious deviation from linear mixing line, DOC was also considered to behave mostly conservatively in the estuary.

Estimation of HS flux from the Penzé catchment using intercepts of the linear model (Eq. (2)) gave $220 \pm 40 \mathrm{tC} \operatorname{year}^{-1}$ (DWM: $2.1 \mathrm{mgC} \mathrm{L}^{-1}$ ). The DOC flux was also calculated by using intercepts from linear DOC$\mathrm{S}$ regressions. This gave $360 \pm 60 \mathrm{tC}$ year $^{-1}$ (DWM: $3.5 \mathrm{mgC} \mathrm{L}^{-1}$ ). The contribution of HS to the DOM flux was therefore $60 \pm 20 \%$. It is worth noting that the approximate POC flux in this system (estimated from a POC concentration in SPM of $\sim 10 \%$ and a particle flux of $\sim 3 \times 10^{6} \mathrm{~kg}$ year $^{-1}$; Verney et al., 2008) is $\sim 300 \mathrm{tC}_{\text {year }}{ }^{-1}$. For comparative purposes with other systems, we determined specific annual fluxes. HS and DOM specific loads were $16 \pm 4$ and $25 \pm 5 \mathrm{kgC} \mathrm{ha}^{-1}$ year $^{-1}$, respectively.

While mixing model comparisons were supportive of conservative HS behaviour, we quantified potential HS loss during estuarine transport. For this purpose, tangents to the second-order models at $S=34$ were calculated and the intercepts $\left(a_{\mathrm{i}}^{*}\right)$ considered to represent the effective zero-salinity end member (Officer, 1979). Based on these estimates, the potential HS loss across the estuary was $\sim 60 \mathrm{tC}$ year $^{-1}$ out of the initial fluvial load of

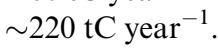

\section{DISCUSSION}

\subsection{Dynamics of DOM and HS in the Penzé river}

Evolution of the DOC concentrations has been studied in various fluvial systems and, according to Cauwet
(2002), there is no common rule. Several studies, however, have observed that DOC increases rapidly at the beginning of flood events then rapidly declines because of concomitant depletion of the readily mobile DOC pool and dilution (e.g., Laudon and Bishop, 1999; Buffam et al., 2001; Dalzell et al., 2007). In small agricultural watersheds it has been shown that DOC changes are principally controlled by water discharge $(Q)$. For example, Dalzell et al. (2007) have shown that DOC concentrations in the Big Pine Creek (Indiana, USA) can be relatively well described with a linear regression between DOC and $\ln (Q)$. Royer and David (2005), in their study of agricultural streams in Illinois (USA), also found a direct relationship between stream water DOC and $Q$ during winter and spring floods, highlighting an allochthonous DOC source from drainage of cropland. For our system, a relatively weak relationship between DOC and $Q$ was found $(\mathrm{DOC}=0.29 * \mathrm{Q}+2.4$, $\left.n=15, R^{2}=0.28\right)$ suggesting a moderate hydrological control. The amount of precipitation over the period proceeding each sampling gave, however, a better estimate of the DOC concentrations (DOC $=0.075 * P_{5}+2.1, \quad n=15$, $R^{2}=0.75$; with $P_{5}$ being the amount of rain in $\mathrm{mm}$ over 5 days) in accordance with the known leaching efficiency of soil organic matter by rain (Cummins, 1974).

Because HS and especially humic substances in stream waters are also considered to originate mainly from soil leaching (Laane, 1981; Noureddin et al., 1987), one can expect a control of this parameter by precipitations. The relationship between HS and $P_{5}$ was also tested (HS $=0.041 * P_{5}+1.6, n=15, R^{2}=0.38$ ) but its accuracy was not as strong as between DOC and $P_{5}$. Indeed, HS levels varied usually within a relatively narrow range $\left(1.8 \pm 0.4 \mathrm{mgC} \mathrm{L}^{-1}, n=11\right)$ and significant increases in concentrations were only encountered under ascending floods: i.e., samplings of January-08 $\left(3.2 \mathrm{mgC} \mathrm{L}^{-1}\right)$, May$08 \quad\left(2.9 \mathrm{mgC} \mathrm{L}^{-1}\right), \quad$ November-08 $\quad\left(4.6 \mathrm{mgC} \mathrm{L}^{-1}\right)$ and November-09 $\left(4.4 \mathrm{mgC} \mathrm{L}^{-1}\right)$. It is worth noting that $\mathrm{HS}$

Table 2

Results of HS-S fitting with linear model ( $\mathrm{HS}=a+b \mathrm{~S}$ ) and second-order model ( $\mathrm{HS}=a+b \mathrm{~S}+c \mathrm{~S}^{2}$ ) for each sampling campaign. $F_{\text {exp }}$ and $F_{\text {th }}$ are values of the $F$-test: under the null hypothesis of this test $\left(F_{\exp }<F_{\text {th }}\right)$, the mixing was considered as being not significantly nonconservative (i.e. conservative). The last three columns indicate parameters which were used for determining HS fluxes over the year 2008: $a_{i}$ is the intercept of the linear model fitting (river end-member concentrations in $\mathrm{mgC} \mathrm{L}^{-1}$ ), $a_{\mathrm{i}}^{*}$ is the effective zero-salinity end-member concentration $\left(\mathrm{mgC} \mathrm{L}^{-1}\right), Q_{7, i}$ is the water discharge $\left(\mathrm{m}^{3} \mathrm{~s}^{-1}\right)$ over the week preceding each sampling campaign. Confidence intervals at the $95 \%$ level are also given for $a_{i}$.

\begin{tabular}{|c|c|c|c|c|c|c|c|c|c|c|}
\hline Sampling date & Linear HS-S fitting & $R^{2}$ & Second-order HS-S fitting & $R^{2}$ & $n$ & $F_{\text {exp }}$ & $F_{\text {th }}$ & $a_{i}$ & $a_{i}^{*}$ & $Q_{7, i}$ \\
\hline 7-January-08 & $\mathrm{HS}=-0.095 \mathrm{~S}+2.78$ & 0.77 & $\mathrm{HS}=0.0026 \mathrm{~S}^{2}-0.175 \mathrm{~S}+3.09$ & 0.82 & 12 & 1.9 & 5.9 & $2.78 \pm 0.58$ & 0.10 & 2.37 \\
\hline 4-February-08 & $\mathrm{HS}=-0.077 \mathrm{~S}+2.33$ & 0.73 & $\mathrm{HS}=0.0016 \mathrm{~S}^{2}-0.130 \mathrm{~S}+2.54$ & 0.76 & 12 & 1.1 & 5.9 & $2.33 \pm 0.54$ & 0.66 & 4.7 \\
\hline 3-March-08 & $\mathrm{HS}=-0.038 \mathrm{~S}+1.25$ & 0.91 & $\mathrm{HS}=0.0005 \mathrm{~S}^{2}-0.054 \mathrm{~S}+1.31$ & 0.93 & 12 & 1.9 & 5.9 & $1.25 \pm 0.13$ & 0.98 & 2.9 \\
\hline 1-April-08 & $\mathrm{HS}=-0.038 \mathrm{~S}+1.15$ & 0.64 & $\mathrm{HS}=0.0014 \mathrm{~S}^{2}-0.080 \mathrm{~S}+1.31$ & 0.71 & 12 & 1.8 & 5.9 & $1.15 \pm 0.31$ & -0.30 & 4.5 \\
\hline 14-May-08 & $\mathrm{HS}=-0.069 \mathrm{~S}+2.23$ & 0.77 & $\mathrm{HS}=0.0012 \mathrm{~S}^{2}-0.107 \mathrm{~S}+2.37$ & 79 & 12 & 0.8 & 5.9 & & 0.97 & 1.9 \\
\hline 13-June-08 & $\mathrm{HS}=-0.048 \mathrm{~S}+1.74$ & 0.84 & $\mathrm{HS}=8 \mathrm{E}-05 \mathrm{~S}^{2}-0.050 \mathrm{~S}+1.75$ & 0.84 & 12 & 0.1 & 5.9 & $1.74 \pm 0.23$ & 1.66 & 2.5 \\
\hline 15-July-08 & $\mathrm{HS}=-0.049 \mathrm{~S}+1.88$ & 0.84 & $\mathrm{HS}=-0.0004 \mathrm{~S}^{22}-0.035 \mathrm{~S}+1.83$ & 0.84 & 12 & 0.3 & 5.9 & $1.88 \pm 0.24$ & 2.33 & 1.5 \\
\hline 27-August-08 & $\mathrm{HS}=-0.061 \mathrm{~S}+2.09$ & 0.88 & $\mathrm{HS}=0.0006 \mathrm{~S}^{2}-0.082 \mathrm{~S}+2.18$ & 0.89 & 11 & 0.6 & 5.3 & $2.09 \pm 0.29$ & 1.45 & 0.9 \\
\hline 25 -September- 08 & $\mathrm{HS}=-0.050 \mathrm{~S}+1.79$ & 0.93 & $\mathrm{HS}=0.0006 \mathrm{~S}^{2}-0.070 \mathrm{~S}+1.87$ & 0.95 & 12 & 1.8 & 5.9 & $1.79 \pm 0.15$ & 1.15 & 1.5 \\
\hline 23-October-08 & $\mathrm{HS}=-0.063 \mathrm{~S}+2.48$ & 0.95 & $\mathrm{HS}=-0.0008 \mathrm{~S}^{22}-0.038 \mathrm{~S}+2.39$ & 0.97 & 12 & 2.6 & 5.9 & $2.48 \pm 0.16$ & 3.28 & 1.4 \\
\hline 25-November-08 & $\mathrm{HS}=-0.140 \mathrm{~S}+4.86$ & 0.93 & $\mathrm{HS}=-0.0008 \mathrm{~S}^{2}-0.117 \mathrm{~S}+4.78$ & 0.93 & 12 & 0.3 & 5.9 & $4.86 \pm 0.41$ & 5.71 & 3.8 \\
\hline 10 -December-08 & $\mathrm{HS}=-0.036 \mathrm{~S}+1.43$ & 0.63 & $\mathrm{HS}=2 \mathrm{E}-05 \mathrm{~S}^{2}-0.037 \mathrm{~S}+1.43$ & 0.63 & 12 & 0.1 & 5.9 & $1.43 \pm 0.31$ & 1.41 & 8.9 \\
\hline 4-May-09 & $\mathrm{HS}=-0.032 \mathrm{~S}+1.30$ & 0.99 & $\mathrm{HS}=0.0002 \mathrm{~S}^{2}-0.038 \mathrm{~S}+1.35$ & 0.99 & 6 & 0.8 & 10 & & & \\
\hline 17-July-09 & $\mathrm{HS}=-0.043 \mathrm{~S}+1.52$ & 0.86 & $\mathrm{HS}=0.0008 \mathrm{~S}^{2}-0.072 \mathrm{~S}+1.64$ & 0.89 & 6 & 0.7 & 10 & & & \\
\hline 13-November-09 & $\mathrm{HS}=-0.146 \mathrm{~S}+4.74$ & 0.93 & $\mathrm{HS}=0.0018 \mathrm{~S}^{2}-0.205 \mathrm{~S}+4.98$ & 0.94 & 6 & 0.5 & 10 & & & \\
\hline
\end{tabular}


amounts were particularly high in November 2008 and November 2009. For explaining them, it must be considered that November precipitations followed relatively long dry periods. This allowed accumulation of organic matter on soils which is certainly enhanced in this season by falling leaves and other plant debris. Furthermore, the residence time of organic matter in soils has been identified as being one of the key factors for its humification (Jastrow et al., 2007). Another element that could contribute to the export of organic matter and HS under autumnal floods is the fall tillage which is known to increase soil sensitivity to erosion (Robert, 2001). Regardless, this time of the year appears to be a key period when a subsequent amount material is exported. In order to confirm this hypothesis, an additional sampling was conducted in winter 2012 under ascending floods (02-January, $Q=8.5 \mathrm{~m}^{3} \mathrm{~s}^{-1}$ ). Concentration of HS was $3.3 \mathrm{mgC} \mathrm{L}^{-1}$ (in contrast to the $\sim 4.5 \mathrm{mgC} \mathrm{L}^{-1}$ observed during the first autumnal flooding) confirming that flushing of HS may occur mainly under the first strong autumnal precipitations.

Plant and vegetable crops are not the only source of DOC and HS to consider. In their model of global DOM export by rivers, Harrison et al. (2005) estimated that dissolved organic nitrogen (DON) in rivers such as the Seine or the Mississippi comes mainly from manure and fertilizer application. Similarly, modelling and direct measurements in the Hudson system indicate that much of the organic $\mathrm{C}$ comes from the agricultural subwatersheds (Howarth et al., 1992; Phillips and Hanchar, 1996).

Because extensive agricultural activities are taking place on the Penzé catchments, animal manure as a potential source of DOC in our system has been evaluated (Table 3). It is worth noting that, considering the high contribution of HS to the DOC pool in the Penzé waters, the outcomes emerging from the following assessment will be also relevant to the humic fraction. First, we considered the number of animals (poultry, pigs and cattle) living on the catchment area and the expected amount of waste material produced by these animals (Biomasse Normandie, 2002). Secondly, a literature survey on concentrations of water extractable organic carbon (WEOC) of various animal wastes, including cattle manure (CM), pig manure (PM) and poultry litter (PL), was conducted (Bernal et al., 1998; Huang et al., 2004; Zmora-Nahum et al., 2005; Angers et al., 2006; Aira et al., 2007; Gattinger et al., 2007; Guo et al., 2009; Table 3). Some discrepancies were found between studies, however, an average WEOC concentration of $12 \mathrm{mg} \mathrm{g}^{-1}$ for all manure types was retained as it is in accordance with most of the reports. It should be also taken into account that a substantial amount of manure is composted before its application on soils. According to various authors (e.g., Hue and Liu, 1995; Bernal et al., 1998), this leads to a consistent decrease in WEOC. Hence, a lower WEOC value was used (i.e., $\left.5 \mathrm{mg} \mathrm{g}^{-1}\right)$ for all kind of composted manure $\left(\mathrm{PL}_{\mathrm{C}}\right.$, $\mathrm{PM}_{\mathrm{C}}, \mathrm{CM}_{\mathrm{C}}$ ). According to our estimation, the potential DOC flux from farming is $490 \mathrm{tC}$ year $^{-1}$ with the majority arising from cattle $(55 \%)$ and pig (30\%). Keeping in mind that substantial uncertainties are associated with the various values used for this estimation, it shows, however, when comparing this DOC source with the DOC flux crossing the estuary $\left(370 \pm 80 \mathrm{tC}\right.$ year $\left.^{-1}\right)$, that leaching of animal manure could contribute a significant proportion, if not the majority, of the exported DOC. Because HS are potentially present at high levels in manure (e.g., Hsu and Lo, 1999), such a source should also represent the main input of dissolved HS to the Penzé waters.

It must be pointed out, however, that several sinks are potentially present over the organic carbon route, from manured soils to the estuary, which could drive down the amount of exported DOC and HS. First, organic matter (including colloidal DOC) is known to be partly retained on mineral soils, mainly through sorption on iron and aluminium hydroxides (e.g., McDowell and Wood, 1984; Moore et al., 1992). Secondly, a substantial amount of this organic matter could have been respired before being leached from soils (Guo et al., 2009; Sissoko and Kpomblekou, 2010) or within the stream path (Cole and Caraco, 2001). For DOC exported from agricultural soils, Royer and David (2005) estimated that approximately a fifth of it was bioavailable in streams. On the other hand, stream production of DOC by algal development is also expected (Minshall, 1978). From the low DOC values we observed in summer and early fall, this source appears, however, to be limited in the Penzé.

Given the potential origin of the DOC in the Penzé system, manure characteristics should be examined in order to explain the variation in HS over the annual cycle. In particular, it is important to understand why (1) HS-to-DOC contribution increased significantly from spring to summer and (2) why HS colloidal distribution was modified during the same period.

At first, composting is an important process to be considered as it is known to modify the organic matter by increasing its degree of humification and by enhancing its potential as a soil organic fertilizer (Plaza et al., 2004). For pig manure, Hsu and Lo (1999) determined that HS accounted for $28 \%$ of the organic matter at the beginning of a composting experiment and that this contribution rapidly increased to a maximum proportion of about $43 \%$ after 1 month. An increase of HS levels has been also reported for cattle manure (Inbar et al., 1989). Similarly, for a municipal waste, Chefetz et al. (1998) found that the humic-like contribution of the water soluble organic matter increased during the late stages of composting. It is worth noting that ambient temperature could lead to substantial differences in the properties of composts. According to Tiquia et al. (1997), based on a pig-manure sawdust litter experiment, warmer temperatures leads to a greater formation of humic substances and also to an increase of the humic acids-to-fulvic acids proportion. Similarly, the increasing of air/soil temperature and solar radiation, which mainly occur in April-May in our system, had probably enhanced the humification of manure during its stay on soils (Kawahigashi, 2006). Changes of the quality of DOM by bacterial activity in stream waters and river sediments are also temperature dependant (Fischer et al., 2002). However, the bacterial activity in stream does not necessarily lead to an increase of the humic fraction (Volk et al., 1997). At this stage, it is worth remembering that increase of the HS:DOC ratio in our system was mainly due to a decrease in DOC rather than an increase in HS. This can result from the change in supply of manure to the cultivated 
soils (Fig 2c); fresh manure application being forbidden from July to January whereas composted manure application is roughly allowed throughout the year. This decrease in DOC (and not in HS) can also be linked to the degradation, under increasing temperatures and solar radiation, of the most labile species.

The major change we observed in the size fractionation of HS was an increasing contribution of the smaller compounds between May and July 09. This could be also partly explained by the bacterial activity. Indeed, in has been shown by several studies (e.g., Amon and Benner, 1996; Hedges et al., 2000; Kaiser and Benner, 2009) that bioreactivity of organic matter decreases along a continuum of size, with larger sized organic matter being more reactive than smaller sized organic matter. Similar to microbial degradation, photochemical degradation also promotes transformation of organic matter (Dahlen et al., 1996; Lepane et al., 2003). The fact that the maximum solar radiations were observed over the May-June period in 2009 in our system (Fig. 2b) suggests that such a process could be efficient in modifying HS size.

\subsection{Comparison of fluxes with other agricultural watersheds}

Aitkenhead and McDowell 2000 reviewed the DOC export of a wide range of watersheds (forested, grassland or peat biomes) from tropical to boreal regions and constructed a model that predicts annual riverine DOC flux at local and global scales from soil $\mathrm{C}: \mathrm{N}$ ratio. These authors pointed out, however, the lack of data concerning systems with low soil $\mathrm{C}: \mathrm{N}(<12)$, and particularly agricultural watersheds.
Following their paper, several studies were undertaken in agricultural systems, and most reported DOC fluxes under $20 \mathrm{~kg} \mathrm{ha}^{-1}$ year $^{-1}$ : the Embarras River $\left(11 \pm 5 \mathrm{~kg} \mathrm{ha}^{-1}\right.$ year $^{-1}$; Royer and David, 2005), Big Pine Creek (14-19 kg ha ${ }^{-1}$ year $^{-1}$; Dalzell et al., 2007), the Save River ( $\sim 7 \mathrm{~kg} \mathrm{ha}^{-1}$ year $^{-1}$, Oeurng et al., 2011). Our estimation for the Penzé system $\left(25 \pm 5 \mathrm{~kg} \mathrm{ha}^{-1}\right.$ year $\left.^{-1}\right)$ shows a higher flux than reported elsewhere. Aminot et al. (1990) reported also a flux over $20 \mathrm{~kg} \mathrm{ha}^{-1}$ year $^{-1}$ for the nearby Elorn estuary. There are many interrelated causes that could explain the differences observed from one system to the other: climate, topography, soil characteristics, landuse, type and amount of spreaded manure, residence time of the organic matter on soils and streams, algal developments in streams, etc... The various data published (Aminot et al., 1990; Hope et al., 1997; Royer and David, 2005; Dalzell et al., 2007; Oeurng et al., 2011) for typical agricultural watersheds (Fig. 6) reveals, however, that the mean annual specific water discharge of a river ( $\mathrm{s} Q, \mathrm{~L} \mathrm{~s}^{-1}$ $\mathrm{km}^{-2}$ ) can be a good and simple predictor of its watershed specific DOC export (sDOC, $\mathrm{kg} \mathrm{ha}^{-1} \mathrm{year}^{-1}$ ). The zerointercept linear regression obtained was $\mathrm{sDOC}=1.11 * \mathrm{~s} Q$ $\left(R^{2}=0.91, n=30\right)$.

Following our assessment that HS contributes $60 \pm 20 \%$ to DOC flux, specific HS export is $\mathrm{sHS}=0.67 * \mathrm{~s} Q$ (units: $\mathrm{kgC} \mathrm{ha}{ }^{-1}$ year ${ }^{-1}$ and $\mathrm{L} \mathrm{s}^{-1} \mathrm{~km}^{-2}$, respectively). To our knowledge, no other published studies have estimated the amount of HS exported from agricultural watersheds. Further investigations will be needed in different agricultural systems to examine if such a relationship can be generalized.

Specific annual export of HS in our systems (16 \pm $4 \mathrm{kgC} \mathrm{ha}^{-1}$ year $^{-1}$ ) can be compared to the estimations

Table 3

Data used for assessment of the potential DOC contribution from animal manure. (c indicates composted manure). Note that 12 and $5 \mathrm{mg} \mathrm{g}^{-1}$ have been retained for WEOC values (fresh and composted manure, respectively) because they represent the means from the various cited studies (values from Angers et al. (2006) and Guo et al. (2009) being significantly different were not included).

\begin{tabular}{|c|c|c|c|c|c|c|}
\hline & Cattle & & Pigs & & Poultry & \\
\hline Amount of waste per animal ${ }^{\mathrm{a}}\left(\mathrm{kg} \mathrm{year}^{-1}\right.$, dry matter $)$ & 1930 & & 177 & & 6.61 & \\
\hline Number of animals on the Penzé catchments & 17,500 & & 102,000 & & $1,600,000$ & \\
\hline Amount of waste on the Penzé catchments ( $\mathrm{t}_{\text {year }}{ }^{-1}$, dry matter) & 33,700 & & 18,100 & & 10,600 & \\
\hline & $\mathrm{CM}$ & $\mathrm{CM}_{\mathrm{C}}$ & PM & $\mathrm{PM}_{\mathrm{C}}$ & PL & $\mathrm{PL}_{\mathrm{C}}$ \\
\hline Manure utilization ${ }^{\mathrm{a}}$ WEOC $^{\mathrm{b}}\left(\mathrm{mg} \mathrm{g}^{-1}\right)$ : & $43 \%$ & $57 \%$ & $42 \%$ & $58 \%$ & $31 \%$ & $69 \%$ \\
\hline - Zmora-Nahum et al. (2005) & 9 & 4 & & & & \\
\hline - Gattinger et al. (2007) & 13 & & & & & \\
\hline - Angers et al. (2006) & 25 & & & & & \\
\hline - Huang et al. $(2004)^{c}$ & & & 11 & 6 & & \\
\hline - Huang et al. $(2004)^{\mathrm{d}}$ & & & 13 & 4 & & \\
\hline - Aira et al. (2007) & & & 11 & 3 & & \\
\hline - Bernal et al. $(1998)^{\mathrm{e}}$ & & & & & 13 & 7 \\
\hline - Guo et al. (2009) & & & & & & 40 \\
\hline Retained value & 12 & 5 & 12 & 5 & 12 & 5 \\
\hline DOC source from each kind of manure $\left(\mathrm{tC}\right.$ year $\left.{ }^{-1}\right)$ & 170 & 100 & 90 & 50 & 40 & 40 \\
\hline Total $\left(\mathrm{tC}\right.$ year $\left.{ }^{-1}\right)$ & 490 & & & & & \\
\hline Animal contribution & $55 \%$ & & $30 \%$ & & $15 \%$ & \\
\hline
\end{tabular}

${ }^{a}$ Biomasse Normandie (2002).

${ }^{\mathrm{b}}$ Water extractable organic carbon.

c PM mixed with sawdust at initial $\mathrm{C} / \mathrm{N}$ of 15 .

${ }^{\mathrm{d}} \mathrm{PM}$ mixed with sawdust at initial $\mathrm{C} / \mathrm{N}$ of 30 .

e Mixture of: $27 \% \mathrm{PL}+20 \% \mathrm{PM}+53 \%$ sweet sorghum bagasse. 


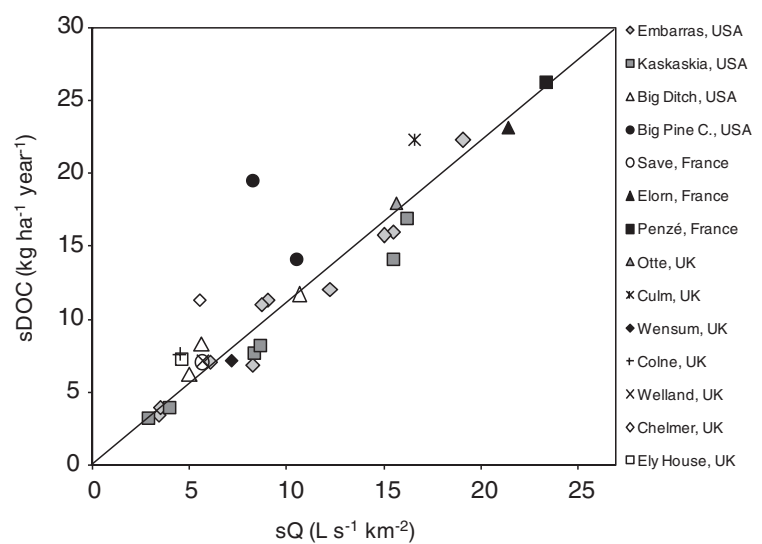

Fig. 6. Relationship between mean annual specific water discharge and specific DOC flux for various agricultural watersheds. The solid line is the zero-intercept linear regression: $\mathrm{sDOC}=1.11 * \mathrm{~s} Q$, $\left(R^{2}=0.91, n=30\right.$, one of the Big Pine Creek points not being used). Data from Embarras, Kaskaskia and Big Ditch: Royer and David (2005); Big Pine Creek: Dalzell et al. (2007); Save: Oeurng et al. (2011); Elorn: Aminot et al. (1990); Otter, Culm, Wensum, Colne, Welland, Chelmer and Ely House: Hope et al. (1997).

made for the Amazon Basin $\left(24 \mathrm{kgC} \mathrm{ha}^{-1}\right.$ year $^{-1}$; Ertel et al., 1986) and for the Swedish/Finnish rivers running to the Gulf of Bothnia $\left(23 \mathrm{kgC} \mathrm{ha}^{-1}\right.$ year $^{-1}$; Pettersson et al., 1997). Although limited because of the small number of HS fluxes quantification from watershed, some important opened questions arise from this comparison. Is the HS export lower in temperate systems as compared to equatorial/subpolar ones or are the agricultural practices actually reduce the HS yield?

\subsection{HS Behaviour along the salinity gradient}

Many studies have shown that dissolved humic acid compounds (HA) are removed during estuarine mixing (e.g., Sharp et al., 1982; Fox, 1983). According to Sholkovitz et al. (1978), approximately $60-80 \%$ of HA is removed by flocculation under elevation of ionic strength. However, it is worth reminding that HA account for a small proportion of HS in fluvial and estuarine waters; the HS pool being rather dominated by fulvic acids which represent $90 \%$ of HS (Aiken, 1985; Thurman, 1985; Nagao et al., 2003). Our data clearly show that HS are slightly affected during their transport to coastal waters (Fig. 5). The preservation of HS under estuarine mixing has been also reported by Tremblay and Gagné (2009) in the Saguenay Fjord (Canada) and has been evidenced by $\delta^{13} \mathrm{C}$ measurements in both the Altamaha and Satilla River estuaries (USA, Otero et al., 2003). McKenna (2004) reported conservative behaviours for HS in the Pawckatuck estuary (USA). However, significant losses (close to $50 \%$ ) were also observed in summer which were attributed to photodegradation. The low reactivity of HS under elevation of the ionic strength in our system is also supported by the consistency of the HS distributions among various molecular weight classes (Fig. 4). Such a consistency was also reported for DOM in the macrotidal Delaware estuary (USA, Harvey and Mannino, 2001).
While the mixing model comparisons (i.e., second-order versus linear) were supportive of conservative HS behaviour, several of the mixing diagrams suggested slight nonconservative behaviour (particularly in the winter and spring; Fig. 5) which cannot be ruled out. Because the freshwater reach is characterized by a strong turbid gradient, with SPM varying from $20 \pm 30 \mathrm{mg} \mathrm{L}^{-1}(n=12)$ at the Penzé village to $200 \pm 100 \mathrm{mg} \mathrm{L}^{-1}(n=12)$ at the salinity front, one could hypothesize that HS removal consists mainly of adsorption onto suspended particles. However, in absence of any obvious elevation of the POC content within the freshwater reaches (Fig. 3), this cannot be confirmed. Removal of HS at higher salinities can ensue from different mechanisms like flocculation or bacterial/photochemical degradation. Because HS removals were mostly observed in winter and spring, when HS are potentially dominated by higher molecular weight species (Fig. 4), flocculation of the largest aggregates can be suspected (Pettersson and Rahm, 1996). An enhanced bacterial degradation of refractory matter can be also hypothesized at this period of higher inputs in labile DOC (which corresponds also to the period of fresh manure application). This process, known as 'the priming effect', has gained considerable interest in the soil literature but has been only very recently taken into account in aquatic sciences (Bianchi, 2011). Conversely, the conservative mixing of HS was always found in summer and autumn. The increase of residence time on catchment soil and the concomitant humification of organic matter during the hotter, drier and lighter period (summer and early autumn) should preserve HS from any removal during their transport across the salinity gradient. It is also worth mentioning that the possibility of simultaneous additions and removals occurring at these seasons giving the semblance of conservative behaviours (McKenna, 2004) cannot be ruled out. Extension of our finding that HS are globally preserved (or slightly removed) during mixing to other estuarine systems needs to be done with care. Such a preservation of HS is more conceivable in small macrotidal systems with short residence times and strong mixing. The nature of the organic matter, which has been identified here as originating mainly from animal manure, is also a probable determinant of HS fate.

An important aspect to consider in the Penzé estuary is the bloom of $A$. minutum that recurs almost every year around June (Erard-Le Denn et al., 2000). Warm conditions and water column stability have been identified as triggers for this species (Maguer et al., 2004) and phosphate inputs from sediment is suspected to control its production (Andrieux-Loyer et al., 2008). Over our survey, the data reveals a striking coincidence between the bloom and the DOC decrease (from May to June-08) which resulted in a higher contribution of HS. Such a change in DOC composition could be an important factor in controlling the competition between phytoplanktonic species, in particular in the ability of $A$. minutum to reach very high concentrations $\left(10^{6}\right.$ cells $\left.\mathrm{L}^{-1}\right)$ to the detriment of other species (Chapelle et al., 2010; and references therein). Several studies have revealed that HS additions can positively affect the growth rate and biomass production of dinoflagellates (Carlsson et al., 1998; Doblin et al., 1999; Gagnon et al., 2005; Heil, 
2005). The concomitant increase in discharge of HS into Swedish rivers and the natural incidence of dinoflagellate blooms over a decade has also been reported (Granéli and Moreira, 1990). How the stimulatory property of HS could be exerted is unknown. Some studies have suggested that HS, because of their metal-binding ligands properties, can modulate the availability of trace elements (Prakash et al., 1973; Toyota, 1994). HS are also suspected to enhance the availability of phosphate which is associated with HS-metal ion complexes (Anderson and Morel, 1982).

\section{CONCLUSION}

Based on the measurement of HS concentrations, HS contribution to DOC and HS colloidal distribution over the annual cycle as well as along the salinity gradient in the Penzé fluvio-estuarine system, we draw the following conclusions. In this watershed under strong agricultural pressure, manuring activities should be the main source of HS and DOC. HS and DOC concentrations in the stream and estuary are highly dependent on hydrological conditions. In particular, high $\mathrm{HS}$ levels in stream $\left(>3 \mathrm{mgC} \mathrm{L}^{-1}\right)$ are always reported under ascending flood confirming that HS mobilization occurs under leaching of soils. The first flood of autumn constitutes a very important period. At this time, HS account for a high proportion of DOM ( $>80 \%$ in carbon) and the flux of HS crossing the estuary is particularly high $(\sim 30 \%$ of the annual discharge in 1 month). This could be the result of a greater retention and transformation of organic matter on soils over the hotter, drier, and lighter preceding period. In the mixing zone of the Penzé estuary, HS display a conservative behaviour, although some limited removals were occasionally observed. Overall, our study argues that preservation of HS, from soils to coastal waters, could be important in small coastal watersheds of the temperate zone. This preservation should be also substantial in the coastal area (English Channel) where strong tidal currents efficiently mix the whole water column, thus limiting both the occurrence of HS in the euphotic zone and the photochemical degradation of these compounds.

\section{REFERENCES}

Aiken G. R. (1985) Isolation and concentration techniques for aquatic humic substances. In Humic Substances in Soil, Sediment, and Water: Geochemistry, Isolation, and Characterization (eds. G. R. Aiken, D. M. McKnight, R. L. Wershaw and P. MacCarthy). Wiley-Interscience, New York, pp. 363-385.

Aira M., Monroy F. and Domínguez J. (2007) Eiseniafetida (Oligochaeta: Lumbricidae) modifies the structure and physiological capabilities of microbial communities improving carbon mineralization during vermicomposting of pig manure. Microb. Ecol. 54, 662-671.

Aitkenhead J. and McDowell W. (2000) Soil C: N ratio as a predictor of annual riverine DOC flux at local and global scales. Global Biogeochem. Cycles 14, 127-138.

Alberts J. J. and Filip Z. (1994) Humic substances in rivers and estuaries of Georgia, USA. Trends Chem. Geol 1, 143-161.

Aminot A., El-Sayed M. A. and Kerouel R. (1990) Fate of natural and anthropogenic dissolved organic carbon in the macrotidal Elorn estuary (France). Mar. Chem. 29, 255-275.
Amon R. M. W. and Benner R. (1996) Bacterial utilization of different size classes of dissolved organic matter. Limnol. Oceanogr. 41, 41-51.

Anderson M. A. and Morel F. M. M. (1982) The influence of aqueous iron chemistry on the uptake of iron by the coastal diatom Thalassiosira weissflogii. Limnol. Oceanogr. 27, 789-813.

Andrieux-Loyer F., Philippon X. and Bally G., et al. (2008) Phosphorus dynamics and bioavailability in sediments of the Penzé Estuary (NW France): in relation to annual P-fluxes and occurrences of Alexandrium minutum. Biogeochemistry 88, 213231.

Angers D. A., Chantigny M. H., Rochette P. and Gagnon B. (2006) Dynamics of soil water-extractable organic C following application of dairy cattle manures. Can. J. Soil Sci. 86, 851-858.

Bernal M. P., Sanchez-Monedero M. A., Paredes C. and Roig A. (1998) Carbon mineralization from organic wastes at different composting stages during their incubation with soil. Agric. Ecosyst. Environ. 69, 175-189.

Bianchi T. S. (2011) The role of terrestrially derived organic carbon in the coastal ocean: a changing paradigm and the priming effect. Proc. Natl. Acad. Sci. U.S.A. 108, 19473-19481.

Biomasse Normandie (2002) Evaluation des quantités actuelles et futures de déchets épandus sur les sols agricoles et provenant de certaines activités - Lot 3: effluents d'élevage. pp. 57. Available at: $\quad<$ http://www.biomasse-normandie.org/IMG/pdf/rapport. pdf $>$.

Blasioli S., Braschi I., Pinna M. V., Pusino A. and Gessa C. E. (2008) Effect of undesalted dissolved organic matter from composts on persistence, adsorption, and mobility of cyhalofop herbicide in soils. J. Agric. Food Chem. 56, 4102-4111.

Brenon I. and Le Hir P. (1999) Modelling the turbidity maximum in the Seine estuary (France): identification of formation processes. Estuar. Coast. Shelf Sci. 49, 525-544.

Buffam I., Galloway J. N., Blum L. K. and Mc Glathery K. J. (2001) A stormflow/baseflow comparison of dissolved organic matter concentrations and bioavailability in an Appalachian stream. Biogeochemistry 53, 269-306.

Burba P., Aster B., Nifant'eva T., Shkinev V. and Spivakov B. Y. (1998) Membrane filtration studies of aquatic humic substances and their metal species: a concise overview: part 1. Analytical fractionation by means of sequential-stage ultrafiltration. Talanta 45, 977-988.

Cai W. J. (2011) Coastal Ocean Carbon Paradox: CO2 Sinks or Sites of Terrestrial Carbon Incineration. Annual Review of Marine Science. 3(1), 123-145.

Carlsson P., Edling H. and Béchemin C. (1998) Interactions between a marine dinoflagellate (Alexandrium catenella) and a bacterial community utilizing riverine humic substances. Aquat. Microb. Ecol. 16(1), 65-80.

Cauwet G. (2002) DOM in the coastal zone. In Biogeochemistry of Marine Dissolved Organic Matter (eds. D. A. Hansell and C. A. Carlson). Academic Press, San Diego, pp. 579-611.

Chanudet V., Filella M. and Quentel F. (2006) Application of a simple voltammetric method to the determination of refractory organic substances in freshwaters. Anal. Chim. Acta 569, 244 249.

Chapelle A., Labry C. and Sourisseau M., et al. (2010) Alexandrium minutum growth controlled by phosphorus: an applied model. J. Mar. Syst. 83, 181-191.

Chefetz B., Hatcher P. G., Hadar Y. and Chen Y. (1998) Characterization of dissolved organic matter extracted from composted municipal solid waste. Soil Sci. Soc. Am. J. 62, 326332.

Chin-Leo G. and Benner R. (1992) Enhanced bacterioplankton production and respiration at intermediate salinities in the Mississippi River plume. Mar. Ecol. Prog. Ser. 87, 87-103. 
Chiou C. T., Malcolm R. L., Brinton T. I. and Kile D. E. (1986) Water solubility enhancement of some organic pollutants and pesticides by dissolved humic and fulvic acids. Environ. Sci. Technol. 20, 502-508.

Cole J. J. and Caraco N. F. (2001) Carbon in catchments: connecting terrestrial carbon losses with aquatic metabolism. Mar. Freshwater Res. 52, 101-110.

Cory R. M., Miller M. P., McKnight D. M., Guerard J. J. and Miller P. L. (2010) Effect of instrument-specific response on the analysis of fulvic acid fluorescence spectra. Limnol. Oceanogr. Methods 8, 67-78.

Cummins K. W. (1974) Structure and function of stream ecosystems. BioScience 24, 631-641.

Dahlen J., Bertilsson S. and Pettersson C. (1996) Effects of UV-A irradiation on dissolved organic matter in humic surface waters. Environ. Int. 22, 501-506.

Dalzell B. J., Filley T. R. and Harbor J. M. (2007) The role of hydrology in annual organic carbon loads and terrestrial organic matter export from a midwestern agricultural watershed. Geochim. Cosmochim. Acta 71, 1448-1462.

Dittmar T. and Kattner G. (2003) The biogeochemistry of the river and shelf ecosystem of the Arctic Ocean: a review. Mar. Chem. 83, 103-120.

Doblin M. A., Blackburn S. I. and Hallegraeff G. M. (1999) Growth and biomass stimulation of the toxic dinoflagellate Gymnodinium catenatum (Graham) by dissolved organic substances. J. Exp. Mar. Biol. Ecol. 236, 33-47.

Ehrhardt M. (1984) Marine gelbstoff. In The Handbook of Environmental Chemistry. Springer, pp. 63-77.

Erard-Le Denn E., Chrétiennot-Dinet M. J. and Probert I. (2000) First report of parasitism on the toxic dinoflagellate Alexandrium minutum Halim. Estuar. Coast. Shelf Sci. 50(1), 109113.

Ertel J. R., Hedges J. I., Devol A. H., Richey J. E. and Ribeiro M. N. G. (1986) Dissolved humic substances of the Amazon River system. Limnol. Oceanogr. 31, 739-754.

Filoso S., Martinelli L. A. and Williams M. R., et al. (2003) Land use and nitrogen export in the Piracicaba River basin, Southeast Brazil. Biogeochemistry 65(3), 275-294.

Fischer H., Sachse A., Steinberg C. E. W. and Pusch M. (2002) Differential retention and utilization of dissolved organic carbon by bacteria in river sediments. Limnol. Oceanogr. 47, $1702-1711$.

Fox L. (1983) The removal of dissolved humic acid during estuarine mixing. Estuar. Coast. Shelf Sci. 16, 431-440.

Gagnon R., Levasseur M., Weise A. M., Fauchot J., Campbell P. G. C., Weissenboeck B. J., Merzouk A., Gosselin M. and Vigneault B. (2005) Growth simulation of Alexandrium tamarense (Dinophyceae) by humic substances from the Manicouagan River (Eastern Canada). J. Phycol. 41, 489-497.

Gattinger A., Höfle M. G., Schloter M., Embacher A., Böhme F., Munch J. C. and Labrenz M. (2007) Traditional cattle manure application determines abundance, diversity and activity of methanogenic Archaea in arable European soil. Environ. Microbiol. 9, 612-624.

Granéli E. and Moreira M. O. (1990) Effects of river water of different origin on the growth of marine dinoflagellates and diatoms in laboratory cultures. J. Exp. Mar. Biol. Ecol. 136, 89106.

Guo M., Labreveux M. and Song W. (2009) Nutrient release from bisulfate-amended phytase-diet poultry litter under simulated weathering conditions. Waste Manage. 29, 2151-2159.

Harrison J. A., Caraco N. and Seitzinger S. P. (2005) Global patterns and sources of dissolved organic matter export to the coastal zone: results from a spatially explicit, global model. Global Biogeochem. Cycles 19, 1-16.
Harvey H. R. and Mannino A. (2001) The chemical composition and cycling of particulate and macromolecular dissolved organic matter in temperate estuaries as revealed by molecular organic tracers. Org. Geochem. 32(4), 527-542.

Hedges J. I., Keil R. G. and Benner R. (1997) What happens to terrestrial organic matter in the ocean? Org. Geochem. 27, 195212.

Hedges J. I., Mayorga E. and Tsamakis E., et al. (2000) Organic matter in Bolivian tributaries of the Amazon River: a comparison to the lower mainstream. Limnol. Oceanogr. 45 , 14491466.

Heil C. A. (2005) Influence of humic, fulvic and hydrophilic acids on the growth, photosynthesis and respiration of the dinoflagellate Prorocentrum minimum (Pavillard) Schiller. Harmful Algae 4(3), 603-618.

Hernes P. J. and Benner R. (2003) Photochemical and microbial degradation of dissolved lignin phenols: implications for the fate of terrigenous dissolved organic matter in marine environments. J. Geophys. Res. 108, 9.

Hope D., Billett M. F., Milne R. and Brown T. A. W. (1997) Exports of organic carbon in British Rivers. Hydrol. Process 11, 325-344.

Howarth R. W., Marino R., Garritt R. and Sherman D. (1992) Ecosystem respiration and organic carbon processing in a large, tidally influenced river: the Hudson River. Biogeochemistry 16, 83-102.

Hsu J.-H. and Lo S.-L. (1999) Chemical and spectroscopic analysis of organic matter transformations during composting of pig manure. Environ. Pollut. 104, 189-196.

Huang G. F., Wong J. W. C., Wu Q. T. and Nagar B. B. (2004) Effect of $\mathrm{C} / \mathrm{N}$ on composting of pig manure with sawdust. Waste Manage. 24, 805-813.

Hue N. V. and Liu J. (1995) Predicting compost stability. Compost Sci. Util. 3, 8-15.

Inbar Y., Chen Y. and Hadar Y. (1989) Solid-state carbon-13 nuclear magnetic resonance and infrared spectroscopy of composted organic matter. Soil Sci. Soc. Am. J. 53, 1695-1701.

Jastrow J. D., Amonette J. E. and Bailey V. L. (2007) Mechanisms controlling soil carbon turnover and their potential application for enhancing carbon sequestration. Climatic Change 80, 5-23.

Jay D. A. and Musiak J. D. (1994) Particle trapping in estuarine tidal flows. J. Geophys. Res. 99, 20445-20461.

Kaiser K. and Benner R. (2009) Biochemical composition and size distribution of organic matter at the Pacific and Atlantic timeseries stations. Mar. Chem. 113(1-2), 63-77.

Kawahigashi M. (2006) Fate of dissolved organic matter (DOM) in forest tundra soil systems with differing permafrost regime. In Symptom of Environmental Change in Siberian Permafrost Region. pp. 135-149. Available at: <http://www.agr.hokudai.ac.jp/env/ctc_siberia/pdf_book/15_Kawahigashi.pdf $>$.

Kieber R. J., Zhou X. and Mopper K. (1990) Formation of carbonyl compounds from UV-induced photodegradation of humic substances in natural waters: fate of riverine carbon in the sea. Limnol. Oceanogr. 35, 1503-1515.

Köhler H., Meon B., Gordeev V. V., Spitzy A. and Amon R. M. W. (2003) Dissolved organic matter (DOM) in the estuaries of $\mathrm{Ob}$ and Yenisei and the adjacent Kara Sea, Russia. Siberian river run-off in the Kara sea: characterization, quantification, variability, and environmental significance. Proc. Mar. Sci 6, 281-308.

Laane R. (1981) Composition and distribution of dissolved fluorescent substances in the Ems-Dollart estuary. Neth. J. Sea Res. 15, 88-99.

Laudon H. and Bishop K. H. (1999) Quantifying sources of acid neutralisation capacity depression during spring flood episodes in Northern Sweden. Environ. Pollut. 105, 427-435. 
Lepane V., Persson T. and Wedborg M. (2003) Effects of UV-B radiation on molecular weight distribution and fluorescence from humic substances in riverine and low salinity water. Estuar. Coast. Shelf Sci. 56(1), 161-173.

Lohrenz S. E., Cai W. J., Chen F., Chen X. and Tuel M. (2010) Seasonal variability in air-sea fluxes of $\mathrm{CO} 2$ in a riverinfluenced coastal margin. J. Geophys. Res. 115, C10034.

Lorenzen C. J. (1967) Determination of chlorophyll and pheopigments: spectrophotometric equations. Limnol. Oceanogr. 12, 343-346.

Maguer J. F., Wafar M., Madec C., Morin P. and Erard-Le Denn E. (2004) Nitrogen and phosphorus requirements of an Alexandrium minutum bloom in the Penzé Estuary, France. Limnol. Oceanogr. 49, 1108-1114.

McDowell W. H. and Wood T. (1984) Podzolization: soil processes control dissolved organic carbon concentrations in stream water. Soil Sci. 137, 23-32.

McKenna J. H. (2004) DOC dynamics in a small temperate estuary: simultaneous addition and removal processes and implications on observed nonconservative behavior. Estuar. Coasts 27, 604-616.

Miller W. L. and Moran M. A. (1997) Interaction of photochemical and microbial processes in the degradation of refractory dissolved organic matter from a coastal marine environment. Limnol. Oceanogr. 42, 1317-1324.

Minshall G. W. (1978) Autotrophy in stream, ecosystems. BioScience 28, 767-771.

Moore T. R., De Souza W. and Koprivnjak J. F. (1992) Controls on the sorption of dissolved organic carbon by soils. Soil Sci. 154, 120-129.

Nagao S., Matsunaga T., Suzuki Y., Ueno T. and Amano H. (2003) Characteristics of humic substances in the Kuji River waters as determined by high-performance size exclusion chromatography with fluorescence detection. Water Res. 37, 4159-4170.

Noureddin S., Chevolot L., Senior W. and Courtot P. (1987) Study of dissolved humic substances in the bay of Brest. Océanis 13, 395-403.

Obernosterer I. and Herndl G. J. (2000) Differences in the optical and biological reactivity of the humic and non humic dissolved organic carbon component in two contrasting coastal marine environments. Limnol. Oceanogr. 45, 1120-1129.

Oeurng C., Sauvage S., Coynel A., Maneux E., Etcheber H. and Sánchez-Pérez J.-M. (2011) Fluvial transport of suspended sediment and organic carbon during flood events in a large agricultural catchment in southwest France. Hydrol. Process. 25. http://dx.doi.org/10.1002/hyp. 7999.

Officer C. B. (1979) Discussion of the behaviour of nonconservative dissolved constituents in estuaries. Estuar. Coast. Mar. Sci. 9, 91-94.

Opsahl S. and Benner R. (1997) Distribution and cycling of terrigenous dissolved organic matter in the ocean. Nature 386, $480-482$.

Otero E., Culp R., Noakes J. E. and Hodson R. E. (2003) The distribution and [delta ${ }^{13} \mathrm{C}$ of dissolved organic carbon and its humic fraction in estuaries of southeastern USA. Estuar. Coast. Shelf Sci. 56, 1187-1194.

Pettersson C. and Rahm L. (1996) Changes in molecular weight of humic substances in the Gulf of Bothnia. Environ. Int. 22(5), 551-558.

Pettersson C., Allard B. and Borén H. (1997) River discharge of humic substances and humic-bound metals to the Gulf of Bothnia. Estuar. Coast. Shelf Sci. 44(5), 533-541.

Phillips P. J. and Hanchar D. W. (1996) Water-quality Assessment of the Hudson River Basin in New York and Adjacent States.
U.S. Geological Survey Report 96, 1-76. Available at: <http:// ny.water.usgs.gov/projects/hdsn/report/Retro.pdf $>$.

Plaza C., Hernández D., Garcia-Gil J. C. and Polo A. (2004) Microbial activity in pig slurry-amended soils under semiarid conditions. Soil Biol. Biochem. 36, 1577-1585.

Prakash A., Rashid M. A. and Jensen A. (1973) Influence of humic substances on the growth of marine phytoplankton: diatoms. Limnol. Oceanogr. 18, 516-524.

Quentel F. and Elleouet C. (2001) Square-wave voltammetry of molybdenum-fulvic acid complex. Electroanalysis 13, 10301035.

Quentel F. and Filella M. (2008) Quantification of refractory organic substances in freshwaters: further insight into the response of the voltammetric method. Anal. Bioanal. Chem. 392(6), 1225-1230.

Quentel F., Madec C., Bihan A. L. and Courtot-Coupez J. (1986) Détermination des Substances Humiques en Milieu Marin Par Redissolution Cathodique a L'Electrode à Goutte Pendante de Mercure. Anal. Lett. 19, 325-344.

Quentel F., Madec C. and Courtot-coupez J. (1987) Determination of humic substances in seawater by electrochemistry (mechanisms). Anal. Lett. 20(1), 47-62.

Raymond P. A. and Bauer J. E. (2001) Riverine export of aged terrestrial organic matter to the North Atlantic Ocean. Nature 409, 497-500.

Robert M. (2001) Soil carbon sequestration for improved land management. World Soil Resources Reports 96. Food and Agricultural Organization of the United Nations. Available at: $<$ http://ftp.fao.org/AGL/agll/docs/wsrr96e.pdf $>$.

Rochelle-Newall E. and Fisher T. (2002) Chromophoric dissolved organic matter and dissolved organic carbon in Chesapeake Bay. Mar. Chem. 77(1), 23-41.

Royer T. V. and David M. B. (2005) Export of dissolved organic carbon from agricultural streams in Illinois, USA. Aquat. Sci. Res. Across Boundaries 67, 465-471.

Rocker D., Brinkhoff T., Grüner N., Dogs M. and Simon M. (2012) Composition of humic acid-degrading estuarine and marine bacterial communities. FEMS Microbiol. Ecol. . http:// dx.doi.org/10.1111/j.1574-6941.2011.01269.x.

Seitzinger S., Harrison J., Dumont E., Beusen A. H. W. and Bouwman A. (2005) Sources and delivery of carbon, nitrogen, and phosphorus to the coastal zone: an overview of Global Nutrient Export from Watersheds (NEWS) models and their application. Global Biogeochem. Cycles 19(4), GB4S01.

Sharp J. H., Culberson C. H. and Church T. M. (1982) The chemistry of the Delaware estuary. General considerations. Limnol. Oceanogr. 27, 1015-1028.

Sholkovitz E. R., Boyle E. A. and Price N. B. (1978) The removal of dissolved humic acids and iron during estuarine mixing. Earth Planet. Sci. Lett. 40, 130-136.

Siegenthaler U. and Sarmiento J. L. (1993) Atmospheric carbon dioxide and the ocean. Nature 365, 119-125.

Sissoko A. and Kpomblekou A. K. (2010) Carbon decomposition in broiler litter-amended soils. Soil Biol. Biochem. 42, 543-550.

Spencer R. G. M., Stubbins A. and Hernes P. J., et al. (2009) Photochemical degradation of dissolved organic matter and dissolved lignin phenols from the Congo River. J. Geophys. Res. 114, 12.

Tanaka S., Oba K., Fukushima M., Nakayasu K. and Hasebe K. (1997) Water solubility enhancement of pyrene in the presence of humic substances. Anal. Chim. Acta 337(3), 351-357.

Tipping E., Hilton J. and James B. (1988) Dissolved organic matter in Cumbrian lakes and streams. Freshwater Biol. 19(3), 371-378.

Thurman E. M. (1985) Organic Geochemistry of Natural Waters. Kluwer Academic Publishers, Dordrecht. 
Tiquia S. M., Tam N. F. Y. and Hodgkiss I. J. (1997) Composting of spent pig litter at different seasonal temperatures in subtropical climate. Environ. Pollut. 98, 97-104.

Toyota T. (1994) Growth inhibition of phytoplankton populations cultured in disphotic zone water by insufficient amounts of dissolved organic carbon. J. Oceanogr. 50, 499-514.

Tremblay L. and Gagné J.-P. (2009) Organic matter distribution and reactivity in the waters of a large estuarine system. Mar. Chem. 116(1-4), 1-12.

Verney R., Bassoullet P., Le Hir P., Jestin H. and Sourisseau M. (2008) Hydrodynamics in a Small Muddy Macrotidal Estuary (Penzé Estuary, NW France): From Monitoring to Modeling PECS 2008: Physics of Estuaries and Coastal Seas, Liverpool, England (UK), 25-29th August.

Volk C. J., Volk C. B. and Kaplan L. A. (1997) Chemical composition of biodegradable dissolved organic matter in streamwater. Limnol. Oceanogr. 42, 39-44.
Waeles M., Tanguy V., Lespes G. and Riso R. D. (2008) Behaviour of colloidal trace metals $(\mathrm{Cu}, \mathrm{Pb}$ and $\mathrm{Cd})$ in estuarine waters: an approach using frontal ultrafiltration (UF) and stripping chronopotentiometric methods (SCP). Estuar. Coast. Shelf Sci. 80, 538-544.

Wen L. S., Stordal M. C., Tang D., Gill G. A. and Santschi P. H. (1996) An ultraclean cross-flow ultrafiltration technique for the study of trace metal phase speciation in seawater. Mar. Chem. 55, 129-152.

Zmora-Nahum S., Markovitch O., Tarchitzky J. and Chen Y. (2005) Dissolved organic carbon (DOC) as a parameter of compost maturity. Soil Biol. Biochem. 37, 2109-2116.

Associate editor: Jerome Gaillardet 